\title{
HETEROGENEITY IN THE LABOR MARKET: UNEMPLOYMENT AND NON-PARTICIPATION IN BRAZIL
}

\author{
Marina Ferreira Fortes Aguas * \\ Valéria Lucia Pero ${ }^{\dagger}$ \\ Eduardo Pontual Ribeiro ${ }^{\ddagger}$
}

\begin{abstract}
This article examines the criteria for classification between unemployment and non-participation in the labor force. We analyze the behavior of a non-employed subgroup, called marginally attached to the labor market (those who are not working or searching for a job in the reference week, but are willing to work), to test whether the transitions are similar to either the unemployed or to those non attached to the labor market. We observed that this group is behaviorally distinct and could be considered an intermediate state between the unemployed and those non-participating in the labor force, although closer to the unemployed.
\end{abstract}

Keywords: Unemployment; Non-participation; Transition matrix; Labor market.

\section{Resumo}

O trabalho tem como objetivo analisar a validade dos métodos correntes de distinção entre o desemprego e a inatividade. Para isso, aplica-se uma abordagem empírica baseada no comportamento de uma categoria dos inativos denominados marginalmente ativos, isto é, indivíduos que não estão ocupados e não procuram trabalho, porém têm o desejo de trabalhar. Buscou-se testar se os fluxos entre os estados de atividade e inatividade dos marginalmente ativos são comportamentalmente idênticos aos dos desempregados ou "realmente" inativos. Como resultado, verificouse que as pessoas inativas que desejam trabalhar têm claramente um comportamento distinto daqueles que não procuram e nem desejam trabalhar, estando mais próximas do estado de desemprego.

Palavras-chave: Desemprego; Inatividade: Matriz de transição; Mercado de trabalho.

JEL classification: J60.

DOI: http://dx.doi .org/10.1590/1413-8050/ea471

\footnotetext{
*Economics Institute, UFF, Brazil. E-mail: mariffaguas@gmail.com

† Economics Institute (IE), UFRJ, Brazil. E-mail: valuciapero@gmail.com

‡ Economics Institute (IE), UFRJ, and CNPq researcher, Brazil. E-mail: eribeiro@ie.ufrj.br
} 


\section{Introduction}

A central issue for Statistical Agencies in the world is the definition of unemployment. Determining which members of the non-employed population will be defined as unemployed is of paramount importance in an economy because labor market diagnostics and public policies are based on such definition.

Most countries, including Brazil, make a distinction between unemployed and out-of-the-labor-force individuals based on the job-search criterion. Job searching effort reveals how close individuals are to the labor market. However, this criterion does not highlight the differences observed within each group, especially those not actively searching for a job. Given this scenario, the purpose of this study is to assess the validity of current methods used to distinguish between unemployment and out of the labor force activity in Brazil.

Even though the basic definition of unemployment encompasses job search, there are people who are available for work, but who have not actively looked for a job in the reference week. According to the International Labor Organization (ILO) and the new Brazilian Monthly Employment Survey (PME), conducted by the Brazilian Institute of Geography and Statistics (IBGE), these are classified as "discouraged," also known as marginally attached to the labor market. There exists great controversy in the literature on how to classify these workers, whether they draw nearer those regarded as out of the labor force (those who do not work and have not actively looked for a job) or unemployed (those who do not work but have actively looked for a job).

The empirical analysis follows the seminal work by Jones \& Riddell (1999) and Flinn \& Heckman $(1982,1983)$. These authors propose to assess the similarity between individuals marginally attached, non-participating and unemployed ones through their dynamics. Therefore, the marginally attached are labeled as non-participating if their mobility between labor market states (employed, unemployed and out of the labor force) is similar to the later group. On the other hand, the marginally attached should be considered as unemployed if their dynamics is similar to that of unemployed individuals.

To appraise such similarity, statistical tests will be run on unconditional and conditional transition matrices. Conditional analysis is required to distinguish the dynamics of the marginally attached and of the non-participating from demographic or educational characteristics composition effects between the groups. For example, suppose that the transition into employment is lower for older people. Should the marginally attached have a different age structure than those of the non-participating group, but similar conditional into employment dynamics within age groups, the unconditional dynamics would differ solely due to the age structure. The analysis was carried out for Brazil between 2003 and 2008, based on longitudinal data from the PME/IBGE.

Advancing the main results, we conclude that the marginally attached have different labor market dynamics from other non-employment groups. Their dynamics, as estimated in the transition matrices between labor market states (employed, unemployed, non-attached and marginally attached individuals) are statistically different from both unemployed and non-participating transitions, although closer to the unemployed than to the non-participating group. The marginally attached should not be classified as out of the labor force because their willingness to work pull them closer to labor market activity. These results are similar to those found for countries such as Portu- 
gal, Trinidad and Tobago, Canada and the USA. Our results indicate that a sharper view of a three state labor market requires classifying the marginally attached group as an intermediate category between unemployment and nonparticipation.

\section{Definition of unemployed and non-participation: A brief summary}

Brazil has ratified and adapted the ILO resolutions to its reality. In the Brazilian labor market, the working-age population (WAP) includes individuals aged 10 years or older and is divided into: 1) economically active population (EAP) or labor force, which includes both employed and unemployed individuals; and 2) out-of-the-labor-force or non-participating or economically inactive population (EIP).

According to the IBGE, the term labor force refers to people who are employed or unemployed, or who have been temporarily laid off and have been waiting to be hired again. Employed (EP) are those who held a paid job (paid in kind, goods or benefits) or an unpaid job as a way to help a working household member, either self-employed or as an employee, for at least one hour, in the reference week. Unemployed people (UP) are those who did not work in the reference week, but who actively searched for a job on the last 30 days and who were available for work in that week. Those people who are not employed or unemployed are referred to as out of the labor force.

For example, in 2008, the Brazilian National Household Survey (PNAD), conducted by IBGE, revealed that there were around 160.5 million working age Brazilians. Approximately 92.4 million of these were employed, 7.1 million were unemployed and 61 million were economically inactive. These figures and the identities of the people in each labor market state are in constant change. Between 2007 and 2008, labor force increased to slightly over 1,600 million people. According to (Ehrenberg \& Smith 2000, p.27-28), one can identify four large labor market flows across labor market states:

1. Employed workers who become unemployed by voluntary withdrawal or due to temporary or permanent layoff;

2. Unemployed workers who get a new job contract or who were laid off temporarily and are hired again;

3. Those in the labor force who, being employed or unemployed, can voluntarily withdraw from their job;

4. Those who have never worked or never looked for a job and who expand the labor force by way of rehirings, or those who had withdrawn from the labor market and return to it.

The chart above shows the breakdown of the Brazilian WAP for 2008 and the four large labor market flows, based on PNAD data obtained by the IBGE.

\subsection{Debate on unemployment classification methods}

Each country has social, economic and organizational characteristics that distinguish it from other countries. In view of this fact, when one intends to 


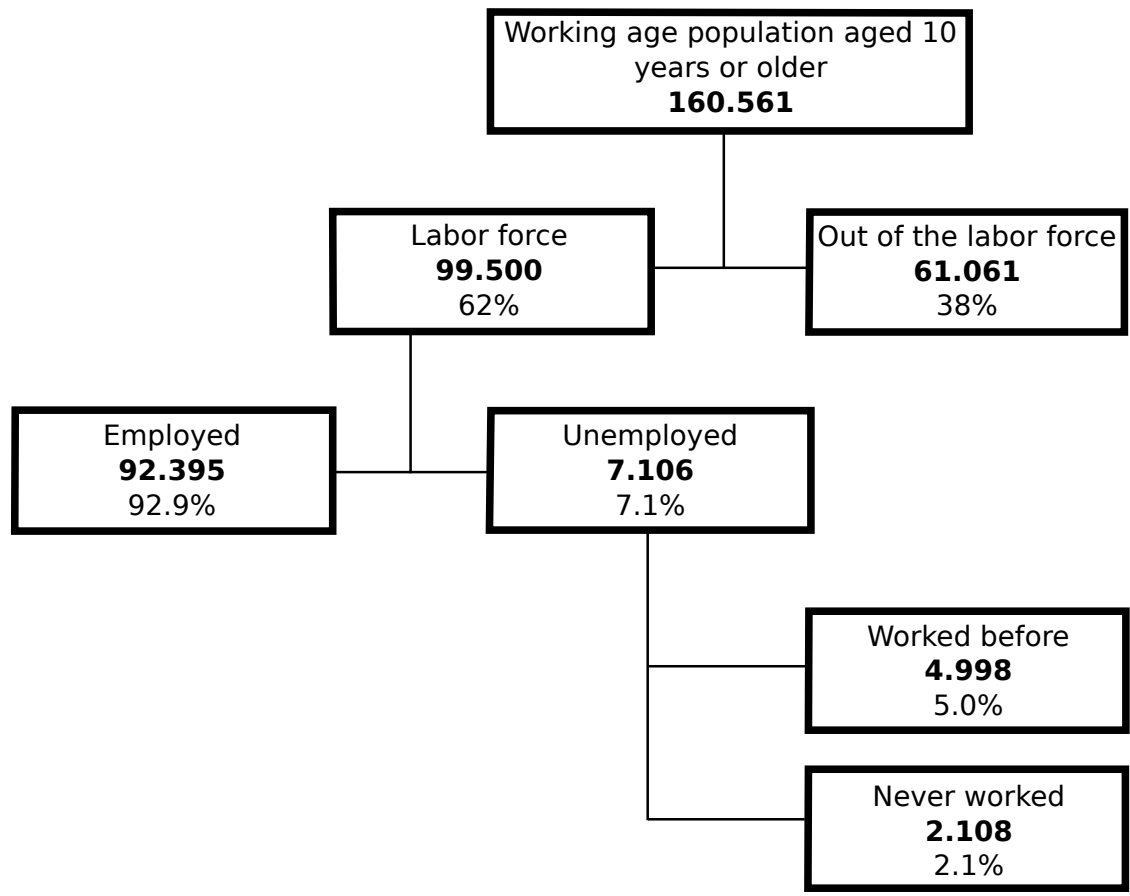

Source: Author's estimates based on data from the 2008 Brazilian National Household Survey (PNAD).

Figure 1: Working-age population in 2008 in the reference week per 1,000 people.

describe the current situation, the statistical method used to select the necessary information must be based on definitions that are consistent with the country's reality, and these can be different from those used as guidelines by other countries.

The definition of standard (or open) unemployment adopted by the ILO and in Brazil is based on three criteria that should occur simultaneously: (a) the person is not working; (b) the person is currently available for work; and (c) the person is looking for a job. These criteria concern the activities of people during a specific reference period. A person should be classified as unemployed only if it has been established that he/she is not employed. The aim of this criterion is to warrant that employment and unemployment be mutually exclusive, but employment should take precedence. Thus, people who hold a transient job will be classified as employed even if they are looking for a job.

Individuals who are not employed or unemployed in the reference period will be classified as out of the labor force. It should be underscored that this category includes those individuals that actively looked for a job prior to the reference period and also those who feel discouraged, but who would like to be working.

Job search is defined by the IBGE as the active process of pursuing an employment goal, i.e., contacting employers; participating in competitive exams; applying for a competitive exam; contacting an employment agency, union or similar organization; replying to a job ad; asking a relative, friend, colleague or in a newspaper ad for a job; taking the initiative to opening a business, etc. 
Nevertheless, in several countries, job search can include not only the socalled "active" methods, but "passive" ones as well. In the United States, for instance, people who passively look for a job, such as searching for a job in newspaper ads, are classified as belonging to the economically inactive population (EIP), whereas in Canada and in many other OECD countries, active and passive job search leads to the classification of an individual as unemployed (Zagorsky 1996). On the other hand, "discouraged" workers, that is, those who would like to be working, but who do not look for a job because they believe a job vacancy is not available, were regarded as unemployed in the USA up to 1967 and in Canada up to 1975, but have been subsequently included among out-of-the-labor-force individuals.

By basing the definition of unemployment upon job search in a given reference period, the search effort reveals how close individuals are to the labor market. Thus, those who do not look for a job, but who want to work or who stopped seeking for a job, do not show a sufficiently close proximity to market activity so as to be classified as unemployed.

In an attempt to have a better understanding of the labor market states and of their heterogeneity, new definitions of unemployment in the mid 1990's in Brazil were implemented. Seade/Dieese ${ }^{1}$ statistics introduced other ways to measure unemployment using the definition of "hidden" unemployment and of discouraged workers. Latter, in 2002, IBGE adopted a similar measure, by introducing a new version of their monthly working survey (PME).

The difference between those who look for a job and those who do not is of utmost importance to labor market analysis, especially for those studies based on flows between different labor market states (employed, unemployed or out of the labor force). The idea concerning job search is often replaced with the notion of productive "waiting" for new jobs, according to Blanchard $\&$ Diamond (1992). The distinction is no longer based on the activities that non-working individuals undertake to look for a job, but rather on the "productivity" of out-of-the-labor-force periods, assessed by the rates of transition to employment. According to these authors, the hiring decisions made by the firms are based on the "ranking" of job candidates. A worker who has been unemployed for a shorter time will be hired. Therefore, duration of unemployment is assumed to be the only criterion for hiring decisions. The longer the duration of unemployment, the less likely an individual will be hired.

This view of labor market operation is supported by the importance of transitions between non-participation and employment. The behavior of certain individuals who do not look for a job, but who are available for work should not be considered too far away from labor market activity, and they could even be included in the group of unemployed or in a different group.

Therefore, it is crucial that each country adopt criteria for the classification of individuals in the labor market that do suit its reality. Capturing a country's actual situation is extremely important for implementing public policies and enhancing their efficacy.

\footnotetext{
${ }^{1}$ SEADE (Sistema Estadual de Análise de Dados) is a foundation attached to the Secretaria de Economia e Planejamento of São Paulo State Government, in partnership with DIEESE (Inter-Union Department of Statistics and Socio-Economic Studies).For further information on the methodology and on the definition of different types of unemployment assessed by the Employment and Unemployment Survey (PED) conducted by Seade/Dieese, see http://www.dieese.org.br/ped.
} 


\section{Empirical framework and international experience}

The empirical analysis for an appropriate definition of unemployment can be described as a Markov model for transitions between labor market states. The first step is to assess heterogeneity in a four-state model: employed (E), unemployed (U), marginally attached $(\mathrm{M})$ and those non-attached (non-participating) to the labor market $(\mathrm{N})$. The first two states correspond to those conventionally measured by labor market surveys (in Brazil, PME and PNAD), whereas the latter two are concerned with the categorization of out-of-the labor-force individuals $(\mathrm{O})$ into two components, $\mathrm{M}$ and $\mathrm{N}$.

Despite the large number of possible definitions for the marginally attached, we focus on those individuals who were considered economically inactive in the reference week (may or may not have searching for employment or even worked in the reference period of 1 year), but had the desire for work. Individuals classified as $\mathrm{N}$ are those who do not look for a job neither want to work, i.e., the ones non-attached to the labor force.

Labor market dynamics is represented by a $4 \times 4$ transition matrix $\mathrm{P}$, where $P_{i j}$ is the probability of an individual being in state $j$ in the subsequent period given that she is currently in state $i$, i.e., the transition rate from state $i$ to $j$. This matrix can be represented by:

$$
P=\left(\begin{array}{llll}
P_{E E} & P_{E U} & P_{E M} & P_{E N} \\
P_{U E} & P_{U U} & P_{U M} & P_{U N} \\
P_{M E} & P_{M U} & P_{M M} & P_{M N} \\
P_{N E} & P_{N U} & P_{N M} & P_{N N}
\end{array}\right)
$$

where, $P_{i j}=d_{i j} / r_{i} . d_{i j}$ stands for the number of individuals in state $i$ in the initial period who move to state $\mathrm{j}$ in the subsequent period; $r_{i}$ is the number of individuals in state $\mathrm{i}$ in the initial period, i.e., $r_{i}=\Sigma_{j} d_{i j}$; and $i, j=E, U, M, N$, are the labor market states, employed (E), unemployed (U), marginally attached $(\mathrm{M})$ and non-attached to the labor force $(\mathrm{N})$. Longitudinal data is required to calculate the transition rates.

The methodology used in this paper to test whether two states of nonemployment have an identical behavior, was originally developed by Flinn \& Heckman $(1982,1983)$ and made popular by Jones \& Riddell (1999). According to these authors, by conveniently controlling the characteristics of individuals, if the transition rate from state $\mathrm{x}$ to $\mathrm{z}$ is identical to the transition rate from state $\mathrm{y}$ to $\mathrm{z}$, the origin state ( $\mathrm{x}$ or $\mathrm{y}$ ) should be considered irrelevant in terms of determination of the transition rate of individuals to state $\mathrm{z}$.

Based on this formulation, the necessary and sufficient condition for the marginally attached and the non-attached individuals to have the same behavior is that the transition probability from $\mathrm{M}$ to $\mathrm{E}$ equals to that from $\mathrm{N}$ to $\mathrm{E}$ and that the transition probability from $M$ to $U$ equals to that from $N$ to $U$, i.e.:

$$
\begin{gathered}
P_{M E}=P_{N E} \\
P_{M U}=P_{N U}
\end{gathered}
$$

Under these circumstances, the four-state Markov model becomes a threestate (E,U and $\mathrm{O}$ ) model, The desire to work does not differentiate individuals as the job search criterion does. 
Alternatively, the conventional job search requirement for characterizing unemployment is likely to be quite restrictive, and those individuals regarded as marginally attached may have a similar behavior than those unemployed, i.e.:

$$
\begin{gathered}
P_{M E}=P_{U E} \\
P_{M N}=P_{U N}
\end{gathered}
$$

In this case, unemployment assessment should be based on the desire to work and not on job search only. The desire to work itself can distinguish unemployed from those inactive, and the job search criteria would not yield any additional information.

If these two conditions are rejected, Jones \& Riddell (1999) suggest that one should expect:

$$
\begin{gathered}
P_{U E}>P_{M E}>P_{N E} \\
P_{U U}>P_{M U}>P_{N U} \\
P_{U N}<P_{M N}<P_{N N}
\end{gathered}
$$

Here, the four-state model for the labor market turns out to be the most appropriate one. Marginally attached individuals should not be included in the non-participating or unemployed groups, for their behavior differs from the latter. These individuals should be placed in a new category. Therefore, it would be rational for statistical agencies to regularly provide statistics with such category.

The empirical analysis developed herein consists in testing the restrictions identified above for Brazil, thus building a more realistic depiction of labor market dynamics in this country. The analysis is based on likelihood ratio tests. The probabilities above are calculated unconditionally and conditional on observable characteristics, because observable characteristics such as age, gender and schooling levels should not be independent of the labor market states. The conditional probabilities are calculated using a multinomial logit model.

The proposal by Jones and Riddle for the USA was applied to several developed countries, such as Portugal (Centeno \& Fernandes 2004), Canada (Jones $\&$ Ridell 2002) and developing countries, such as Trinidad and Tobago (Byrne \& Strobol 2004).

For Portugal, Centeno \& Fernandes (2004) used the individuals dataset of the Employment Survey (ES) for the period between the second quarter of 1992 and the fourth quarter of 2003, for individuals aged 16 to 64 years. Although statistically different from other states, the transition rate of the marginally inactive to employment was similar to the one from unemployment, and clearly higher than those non-participating. These results support the adoption of one more labor market state, given the high probability of future participation in the labor market of individuals who want to work although they do not look for a job.

The analysis for Canada (Jones \& Ridell 2002) uses the Labor Force Survey (LFS) for 1997 to 2000. The marginally attached account for 25 to $35 \%$ of the 
unemployed individuals. Transition flows to employment show that there are stark differences between the unemployed and the marginally attached, since the transition UE (unemployment to employment) amounts to approximately $23 \%$, almost twice as high as that of ME (marginally attached to employment). In addition, the transition NE (non-participation to employment) is close to $3.5 \%$, numerically inferior to that of $\mathrm{ME}$, which also demonstrates a different behavior between $\mathrm{M}$ and $\mathrm{N}$.

For Trinidad and Tobago, Byrne \& Strobol (2004) obtained a similar result to that of Portugal, in which the group of those marginally attached to the labor market has a closer dynamics to that of the unemployed than to those who do not take part in the labor force.

\section{Analysis of results for Brazil}

The analysis starts with the estimation of mean transition rates between the four labor market states (E, U, M, N) and the behavior of transition probabilities throughout the analyzed period. To calculate these transition rates, PME microdata, conducted by the IBGE, for years 2003 to 2008, were used. The PME is a representative monthly rotating panel household survey that investigates the labor market and characteristics of the population living in the urban areas of the largest Brazilian metropolitan regions (Recife, Salvador, Belo Horizonte, Rio de Janeiro, São Paulo and Porto Alegre).

The PME data is collected through interviews with all household dwellers aged 10 years or older. The sample of household units is distributed according to the four reference weeks of the month. Monthly results are obtained by the average of these four reference weeks. The data collection follows a method in which each selected household unit is surveyed during four consecutive months, ignored for eight months and then surveyed again for four months, and finally eliminated from the sample. If during the period (16 months) in which the household unit remains in the sample, the family moves away and another family moves in, the information will be obtained from the new family during the remaining period. The PME is subdivided into eight rotation groups. Every month, 25\% of the sample of household units is replaced, following rotation and panel schemes. Therefore, $50 \%$ of the sample from a given month appears in the same month the following year.

In addition to measuring employment, unemployment and non-participation, the survey allows identifying marginally attached individuals. This is done through a combination of several questions from the questionnaire survey to identify if the individual considered inactive in the reference week would get a job and be available for this.

The study was conducted for individuals classified as household head and the transition rates calculated month-to-month from January 2003 to December 2008. Altogether 1,698,681 observations were selected, which represents 235 million individuals in 2003 and 266 million in 2008. The short time span for dynamics is not restrictive, as turnover rates in Brazil are quite high (Gonzaga 2003). Longer spans (four or twelve months) would reduce and likely bias the sample significantly, given the high attrition rates 


\subsection{Estimates and time variation of transition rates}

The composition of the working-age household heads in metropolitan areas by labor market states considering the period average is $65.09 \%$ employed, $3.67 \%$ unemployed, $29.57 \%$ out of the labor force and $1.67 \%$ of marginally attached. It is interesting to underscore, however, that the marginally attached account for approximately $5.4 \%$ of the individuals classified as out of the labor force by the PME, but correspond to about $45,5 \%$ of the unemployed.

Table 1 shows the mean transition rate estimates for the period. We observe that the strongest labor market state persistence rate is found for employment (EE), followed by out-of-the-labor-market activity (NN). The persistence of the marginally attached (MM) is the lowest. Note that this group is more likely to move to any labor market state, a markedly different pattern from others, perhaps except for the unemployed, who are also more likely to leave the state (UE, UN, UM) than to stay in it (UU).

Table 1: Average Monthly Transition matrix, 2003-2008 - Metropolitan regions - Brazil

\begin{tabular}{lcccc}
\hline State t & \multicolumn{4}{c}{ State $\mathrm{t}+1$} \\
& $\mathrm{E}$ & $\mathrm{U}$ & $\mathrm{N}$ & $\mathrm{M}$ \\
\hline $\mathrm{E}$ & 0.96 & 0.01 & 0.02 & 0.01 \\
$\mathrm{U}$ & 0.21 & 0.55 & 0.13 & 0.10 \\
$\mathrm{~N}$ & 0.05 & 0.02 & 0.92 & 0.01 \\
$\mathrm{M}$ & 0.20 & 0.25 & 0.24 & 0.31 \\
\hline \multicolumn{5}{l}{ Source: Elaborated by the authors based } \\
on PME microdata for 2003 to 2008.
\end{tabular}

The above table obscures the dynamics over the cycle. GDP growth rates varied over the period $(1.15 \%$ in $2003,5.71 \%$ in 2004 , from 3 to $4 \%$ in $2005-6$ and above $5 \%$ in 2007-8). The following graphs show the quarterly mean transition rates for 2003 through 2008 for the selected sample of household heads into employment, unemployment and inactivity. ${ }^{2}$ Each quarterly transition rate corresponds to the weighted average of the monthly rates in the quarter.

Interestingly, the transition rates are relatively stable over time. With regard to exit into employment (Figure 2), the UE and ME rates are close to each other, but the former is slightly higher than the latter. They range between within 18 and $25 \%$. On the other hand, the NE rate is away from the others, always below $6 \%$.

Figure 3 shows the transitions into unemployment. As seen in Table 1, the persistence in unemployment is at a much higher level than the other transitions into unemployment. The mobility into unemployment of the marginally attached is more volatile, while the other form of non-participation presents itself on a stable and low level in any period.

As shown in Figure 4, most individuals who were previously non-participating stayed as such (NN). The proportion of people who came from unemployment is relatively small and constant. Conversely, the transition MN has a greater variability, increasing at the end of the period.

\footnotetext{
${ }^{2}$ The rates can also be seen in Table A.1 in the Appendix.
} 


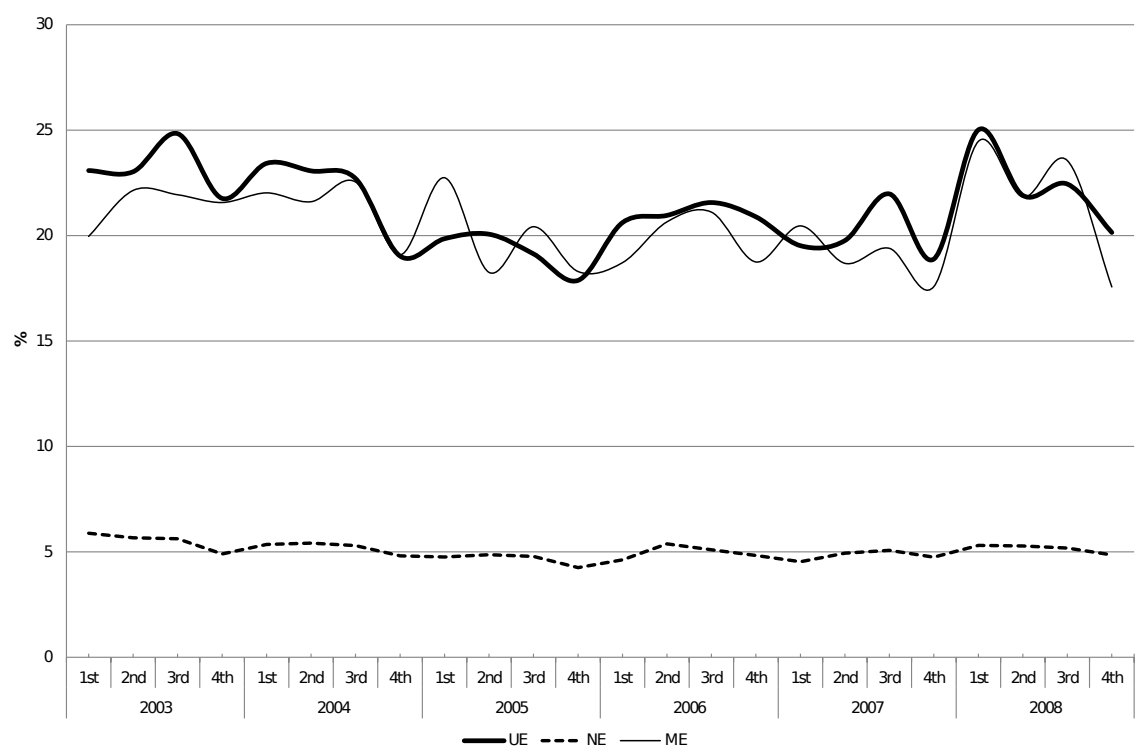

Source: Elaborated by the authors based on the PME microdata for 2003 to 2008 .

Figure 2: Quarterly transition rates to employment.

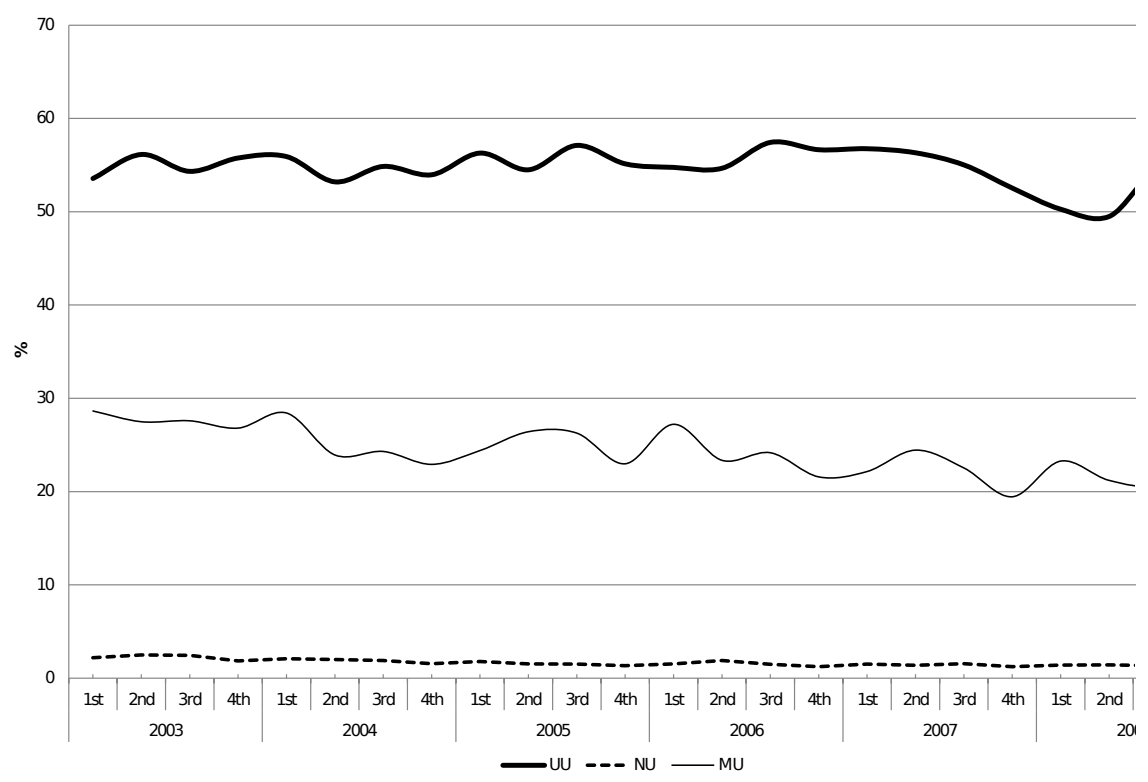

Source: Elaborated by the authors based on the PME microdata for 2003 to 2008 .

Figure 3: Quarterly transition rates to unemployment. 


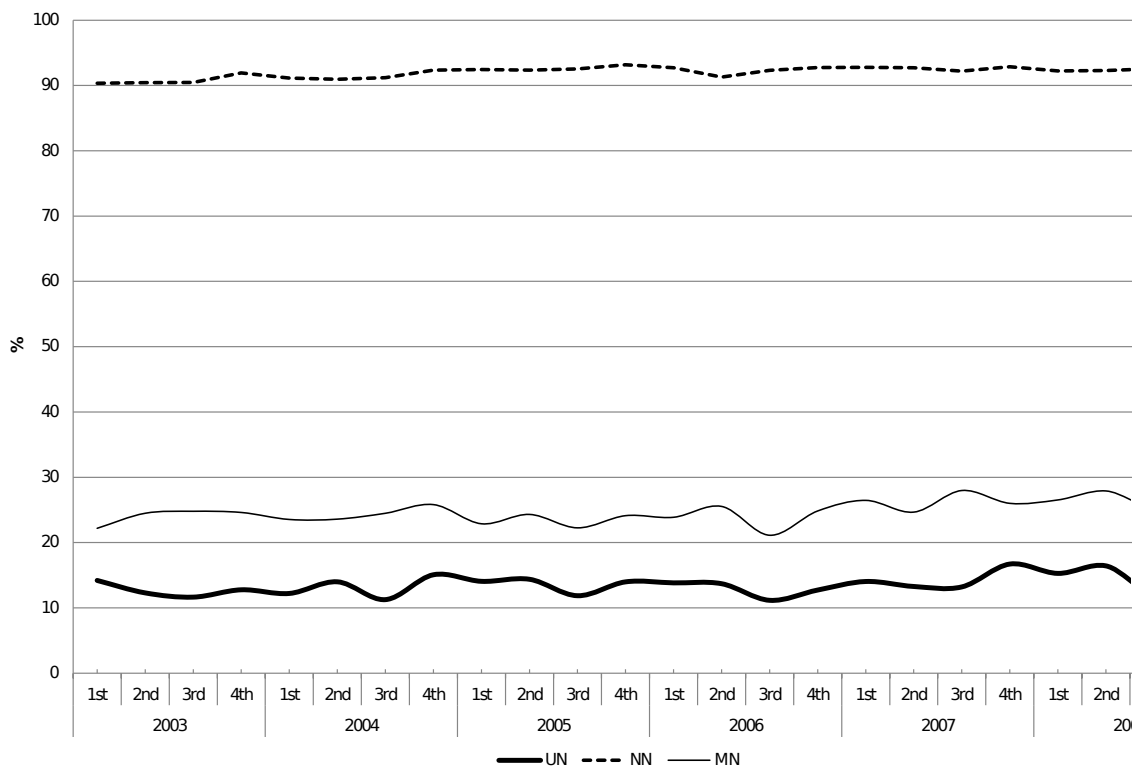

Source: Elaborated by the authors based on the PME microdata for 2003 to 2008.

Figure 4: Quarterly transition rates to non-participation.

This analysis can also be made for the interviewed population, split according to gender. ${ }^{3}$ It suffices to say that the transitions by gender are quite similar to that for the population as a whole. One of the reasons is certainly the restriction in the sample, which takes only the household heads into account. Female household heads have participation rates closer to male household heads. Looking at the migration into employment, the high volatility of ME can be seen for both sexes, as well as its proximity to EU. Men, however, have mobility rates higher than women, regardless of the state of origin.

Transitions into unemployment from inactivity (NU) for both men and women remain at less than 3\% throughout the study period. Persistence into unemployment is more volatile, where the rates for women are higher than those for men. This also occurs on UN and MN transitions.

Tables 2 and 3 show the mean transition matrices according to gender. Note that the exit from unemployment differ between men and women: men tend to move into employment whereas women are more likely to drop out of the labor force or become marginally attached.

To illustrate the dynamic properties of the transition matrix, we estimated the limiting distribution of labor market states, implied by the transition matrix above. The Markov assumption implies that:

$$
\Pi P_{t-1}=P_{t}
$$

where $\Pi$ represents the transition matrix, $P_{t-1}$ is the vector of marginal probabilities in states $(\mathrm{E}, \mathrm{M}, \mathrm{N}, \mathrm{U})$ in quarter $t-1$ and $P_{t}$ is the vector of marginal probabilities in states $(\mathrm{E}, \mathrm{M}, \mathrm{N}, \mathrm{U})$ in quarter $t$. In the long run, a stationary distribution is assumed such that $P_{t-1}=P_{t}=P$. We can write $\Pi P=P$, i.e.,

\footnotetext{
${ }^{3}$ The graphs demonstrate the evolutionary behavior of transition rates between men and women on a quarterly basis can be seen in the appendice, such as the table with the data.
} 
Table 2: Average Monthly Transition matrix for men, 2003-2008 Metropolitan regions - Brazil

\begin{tabular}{lcccc}
\hline State t & \multicolumn{4}{c}{ State $\mathrm{t}+1$} \\
& $\mathrm{E}$ & $\mathrm{U}$ & $\mathrm{N}$ & $\mathrm{M}$ \\
\hline $\mathrm{E}$ & 0.97 & 0.01 & 0.02 & 0 \\
$\mathrm{U}$ & 0.26 & 0.55 & 0.10 & 0.09 \\
$\mathrm{~N}$ & 0.06 & 0.02 & 0.91 & 0.01 \\
$\mathrm{M}$ & 0.25 & 0.26 & 0.20 & 0.29 \\
\hline \multicolumn{5}{l}{ Source: Elaborated by the authors based } \\
on PME microdata for 2003 to 2008.
\end{tabular}

Table 3: Average Monthly Transition matrix for women, 2003-2008 Metropolitan regions - Brazil

\begin{tabular}{lcccc}
\hline State t & \multicolumn{4}{c}{ State $\mathrm{t}+1$} \\
& $\mathrm{E}$ & $\mathrm{U}$ & $\mathrm{N}$ & $\mathrm{M}$ \\
\hline $\mathrm{E}$ & 0.94 & 0.01 & 0.04 & 0.01 \\
$\mathrm{U}$ & 0.15 & 0.55 & 0.17 & 0.12 \\
$\mathrm{~N}$ & 0.04 & 0.02 & 0.93 & 0.01 \\
$\mathrm{M}$ & 0.15 & 0.23 & 0.29 & 0.33 \\
\hline \multicolumn{5}{l}{ Source: Elaborated by the authors based } \\
on PME microdata for 2003 to 2008.
\end{tabular}

$P=(\Pi-I)^{-1}$. Table 4 shows the average 2003-2008 sample distribution and the limiting distribution for the whole population and for men and women.

Table 4: Initial and limiting distribution of the population in the labor market states

\begin{tabular}{lcccccc}
\hline State $\mathrm{t}$ & \multicolumn{2}{c}{ Total } & \multicolumn{2}{c}{ Men } & \multicolumn{2}{c}{ Women } \\
\hline & Initial & Limiting & Initial & Limiting & Initial & Limiting \\
\cline { 2 - 7 } $\mathrm{E}$ & 0.651 & 0.651 & 0.745 & 0.743 & 0.481 & 0.485 \\
$\mathrm{U}$ & 0.036 & 0.034 & 0.032 & 0.031 & 0.043 & 0.040 \\
$\mathrm{~N}$ & 0.297 & 0.300 & 0.210 & 0.214 & 0.454 & 0.454 \\
$\mathrm{M}$ & 0.016 & 0.015 & 0.013 & 0.012 & 0.022 & 0.021 \\
\hline
\end{tabular}

Source: Elaborated by the authors based on PME microdata for 2003 to 2008.

First, it is possible to observe that the initial and extreme-value distributions are quite similar, indicating small variability of the transition rates over time, as shown in the graphs above. Secondly, note the low importance of the "marginally attached" (M) state, as it has the smallest rate in the population. Nevertheless, note that the marginally attached are about $45 \%$ of the unemployed, suggesting that unemployment rates could increase significantly, should we consider the $\mathrm{M}$ group as unemployed. 


\subsection{Behavioral equivalence tests}

After presenting the evolution of transition rates, one should evaluate their similarity using the method developed by Flinn \& Heckman $(1982,1983)$. The authors indicate two equivalence conditions for the marginally attached group to be considered similar, from a behavioral standpoint, with the unemployed group. That is, $P_{M E}=P_{U E}$ e $P_{M N}=P_{U N}$.

Based on table 1, these conditions should be rejected. Despite the fact that the transition probability from unemployment to employment is quite close to the transition probability from marginally attached to employment, the transitions from $\mathrm{M}$ or $\mathrm{U}$ to $\mathrm{N}$ are not similar. The chance of a marginally attached individual to drop out of the labor force is higher than the odds of an unemployed move into non-participation. The result does not change if we segregate by gender (tables 2 and 3 ).

The second condition concerns the behavioral equivalence between $\mathrm{M}$ and $\mathrm{N}$, which would occur if: $P_{M E}=P_{N E}$ e $P_{M U}=P_{N U}$. This condition is clearly rejected for the Brazilian data. Both $P_{M E}$ and $P_{M U}$ are greater than $P_{N E}$ and $P_{N U}$, respectively.

As previously pointed out in Section 2, when these two conditions are rejected, one may expect that:

$$
\begin{gathered}
P_{U E}>P_{M E}>P_{N E} \\
P_{U U}>P_{M U}>P_{N U} \\
P_{U N}<P_{M N}<P_{N N}
\end{gathered}
$$

This is exactly what happens in Brazil. Note also that the difference between $P_{M E}$ and $P_{N E}$ is larger than the difference between $P_{U E}$ and $P_{M E}$ for both sexes throughout the analyzed period, suggesting that the marginally attached state is closer to unemployment than to the non-attached group.

A formal test can be run using asymptotic results for transition matrix probabilities (Formby et al. 2004). The authors generalize the basic results of standard deviations for proportions, available in statistics books, such as, $V\left(P_{M E}\right)=P_{M E}\left(1-P_{M E}\right) / n P_{M}$. In Table 5 , we present the chi-square statistics and the $\mathrm{p}$-values for the above hypotheses. The results reject the hypothesis that transitions of people originally in the marginally attached state have a similar behavior to that of unemployed and out-of-the-labor-force individuals in all of the surveyed years, respectively. Note that the test statistics are higher for the hypothesis of similarity between the marginally attached and out-of-the-labor-force individuals than for the equality hypothesis between marginally attached and unemployed, confirming the evidence above that the marginally attached are a different category, but closer to the unemployed than to the out-of-the-labor-force individuals.

The analysis of the previous table is complemented by testing the equality of the probabilities conditional on the observable characteristics. This avoids the problem of rejecting transition equality due to composition effects, i.e., from the possibility that people in the UE transition have different observable characteristics from those in the ME transition.

Following Flinn \& Heckman (1982) and Jones \& Riddell (1999), a multinomial logit model for the transitions across labor market states was estimated 
Table 5: Equivalence tests for transition probabilities

\begin{tabular}{lcccccc}
\hline Hypothesis & 2003 & 2004 & 2005 & 2006 & 2007 & 2008 \\
\hline$P_{M E}=P_{U E}$ & 1260 & 1171 & 1205 & 1109 & 926 & 942 \\
$P_{M N}=P_{U N}$ & $(0.000)$ & $(0.000)$ & $(0.000)$ & $(0.000)$ & $(0.000)$ & $(0.000)$ \\
\hline$P_{M E}=P_{N E}$ & 107 & 109 & 89 & 103 & 108 & 95 \\
$P_{M U}=P_{N U}$ & $(0.000)$ & $(0.000)$ & $(0.000)$ & $(0.000)$ & $(0.000)$ & $(0.000)$ \\
\hline
\end{tabular}

Source: Elaborated by the authors based on PME microdata for 2003 to 2008 .

Note: $\mathrm{p}$ value statistics in brackets. Test statistics $\times 10^{-4}$. Total weighted sample size: from 105 million (2003) to 122 million (2008) transitions per year.

to compare the behavior of individuals originally in the marginally attached state with the unemployed and out-of-the-labor-force ones. An unrestricted model was estimated, which includes the dummy variable for marginally attached $(\mathrm{M})$ people and the interactions of covariates with this dummy, allowing for the identification of distinct behaviors of the transitions, first from $\mathrm{M}$ and $\mathrm{U}$ (Table A.4 in the Appendix) and later from M and N (Table A.5 in the Appendix). Note that if the (conditional) transition probabilities between ME and UE, for instance, are the same, the restricted and unrestricted models should yield the same results. Thus the test of similarity between transition probabilities based on the marginally attached and unemployed, conditional on the characteristics, is implemented as a likelihood ratio significance test on the coefficients associated with the origin in $\mathrm{M}$ (in relation to the origin in $\mathrm{U}$ ).

To save space, we relegate the underlying multinomial logit tests to the appendix. We point out that the observable characteristics (gender, whether self declared white or not, and age and age squared) are significant in all models.

Table 6: Likelihood ratio test

\begin{tabular}{lccc}
\hline Hypothesis & Total & Men & Women \\
\hline$P_{M E}=P_{U E}$ & 439.41 & 246.9 & 193.36 \\
$P_{M N}=P_{U N}$ & $(0.000)$ & $(0.000)$ & $(0.000)$ \\
$P_{M E}=P_{N E}$ & $2,165.51$ & $1,116.11$ & $1,044.94$ \\
$P_{M U}=P_{N U}$ & $(0.000)$ & $(0.000)$ & $(0.000)$ \\
\hline Source: Elaborated by the authors based on PME \\
microdata for 2003 to 2008. \\
Note: statistics p-value in brackets. Test results are \\
based on Tables A.4 and A.5 in the Appendix. Sample \\
sizes: Men: 24311; Women: 22525.
\end{tabular}

The likelihood ratio test of the restricted versus the unrestricted model allows Checking whether the behavior of transitions of the marginally attached is similar to that of the unemployed or to that of the non-participants. According to the likelihood ratio test results and associated p-values shown in Table 6, the no difference between transitions null hypothesis is rejected, indicating that people originally in $\mathrm{M}$ have a distinct behavior from those in $\mathrm{U}$ or $\mathrm{N}$. This applies to both men and women. The results suggest that the classification into four categories is the one that best describes employment and out-of-the-labor-force activities. Note also that this result is stronger for $\mathrm{N}$, indicating that $\mathrm{M}$ is closer to $\mathrm{U}$ than to $\mathrm{N}$, as observed in the unconditional analysis (Table 5) 
In brief, $\mathrm{M}$ is an intermediate state, with some proximity to labor market activity superior to out of the labor force, but still different from unemployment. Therefore, the use of four labor market states is more adequate to reality.

\section{Conclusion}

The purpose of this study was to assess the validity of the current methods used to distinguish between unemployment and inactivity in Brazil. In particular, the aim was to investigate whether those individuals not searching for a job in the reference week, but desiring to work (the marginally attached) have a distinct behavior from job searchers (the unemployment captured in a conventional way) and from those who do not look for a job and do not want to work (non-participants in the labor force). Longitudinal data were used for this analysis because they allowed observing movements across labor market states. We exploit the information in PME/IBGE microdata that allows us to distinguish between three non-working states (unemployment, non-attached and marginally attached $-\mathrm{U}, \mathrm{N}, \mathrm{M}$, respectively). Our sample covers from 2003 to 2008. The methodology follows Flinn \& Heckman $(1982,1983)$ and made popular by Jones \& Riddell (1999). Here, labor market states are considered different if their dynamics differ.

The major finding was that the marginally attached and the non-participants can be considered different labor market categories, as well as different from unemployment. Both hypotheses of behavioral equivalence, between $U$ and $\mathrm{M}$, and, $\mathrm{N}$ and $\mathrm{M}$ were rejected for Brazil, making it clear that there are differences within the out-of-the-labor-force group. Availability for work represents more than a simple desire; it implies the existence of some proximity to the labor market and significantly increases the probability of transition to employment in the future. The results did not differ by gender and appear both on unconditional and unconditional transition probability tests.

Another result of the study shows that the marginally attached are closer to unemployment than to out of the labor force. This occurs because the difference between $P_{M E}$ and $P_{N E}$ is larger than the difference between $P_{M E}$ and $P_{U E}$ for both sexes throughout the analyzed period. Therefore, $M$ may be seen as an intermediate category, whose behavior lies between the unemployed and those remaining out of the labor force.

These results are similar to the ones obtained for countries such as Portugal, Canada and the USA, but in the latter two, states U and M do not have the level of proximity found for Brazil and Portugal. On the other hand, in Trinidad and Tobago, the results revealed a different behavior of transitions in terms of sex, according to which the equivalence test with the unemployed could not be rejected for men.

So, it would be important that the statistics differentiate the three out-ofemployment states, shedding further light on the variations of the rate of unemployment in the economy. The use of a new category, based on the desire to work and on job seeking, can better describe the characteristics of the Brazilian labor market. 


\section{Bibliography}

Blanchard, O. J. \& Diamond, P. (1992), 'The flow approach to labor markets', American Economic Review 82(2), 354-9.

Byrne, D. \& Strobol, E. (2004), 'Defining unemployment in developing countries: evidence from trinidad and tobago', Journal of Development Economics 73(1), 465-476.

Centeno, M. \& Fernandes, P. A. (2004), 'Heterogeneidade no mercado de trabalho: o que distingue desemprego e inactividade', Boletim Econômico. Banco de Portugal. Lisboa pp. 63-71.

Ehrenberg, R. G. \& Smith, R. S. (2000), Modern Labor Economics: Theory and Public Policy, 7 edn, United States of America.

Flinn, C. J. \& Heckman, J. J. (1982), 'New methods for analyzing structural models of labor force dynamics', Journal of Econometrics (18), 115-68.

Flinn, C. J. \& Heckman, J. J. (1983), 'Are unemployment and out of the labor market behaviorally distinct labor force states?', Journal of Labor Economics 1(1).

Formby, J., Smith, J. \& Zheng, B. (2004), 'Mobility measurement, transition matrices and statistical inference', Journal of Econometrics 120(1), 181-205.

Gonzaga, G. (2003), 'Labor turnover and labor legislation in brazil', Journal Of The Latin America And Caribbean Association 4(1), 165-221.

Jones, S. R. G. \& Ridell, W. C. (2002), Unemployment and non-employment: Heterogeneities in labour market states, Working paper series., Department of Economics, McMaster University, Hamilton, Ontario, Canadá.

Jones, S. \& Riddell, W. (1999), 'The measurement of unemployment: An empirical approach', Econometrica 67(1), 147-62.

Zagorsky, J. L. (1996), 'The effect of definitional differences on us and canadian unemployment rates', Canadian Business Economics 4, 13-21.

\section{Appendix A}


Table A.1: Transition rates (\%) between employment (E), unemployment (U), non attachment $(\mathrm{N})$ and marginal attachment (M) from the 1st quarter of 2003 to the 4th quarter of 2008

\begin{tabular}{|c|c|c|c|c|c|c|c|c|c|c|c|c|c|c|c|c|c|c|c|c|c|c|c|c|c|}
\hline & & \multicolumn{4}{|c|}{2003} & \multicolumn{4}{|c|}{2004} & \multicolumn{4}{|c|}{2005} & \multicolumn{4}{|c|}{2006} & \multicolumn{4}{|c|}{2007} & \multicolumn{4}{|c|}{2008} \\
\hline & & 1 st & $2 n d$ & $3 \mathrm{rd}$ & 4 th & 1 st & 2 nd & $3 \mathrm{rd}$ & 4 th & 1 st & 2 nd & $3 \mathrm{rd}$ & 4 th & 1 st & $2 \mathrm{nd}$ & $3 \mathrm{rd}$ & 4 th & 1 st & $2 \mathrm{nd}$ & $3 \mathrm{rd}$ & 4 th & 1 st & $2 \mathrm{nd}$ & $3 \mathrm{rd}$ & 4 th \\
\hline \multicolumn{26}{|c|}{ Transitions to employment } \\
\hline $\mathrm{E}$ & $\mathrm{E}$ & 95.3 & 95.3 & 95.6 & 95.9 & 95.6 & 95.9 & 95.8 & 96.2 & 96.2 & 96.3 & 96.6 & 96.6 & 96.2 & 95.8 & 96.1 & 96.2 & 96.3 & 96.4 & 96.3 & 96.3 & 96.0 & 96.2 & 96.1 & 96.1 \\
\hline U & $\mathrm{E}$ & 23.1 & 23.0 & 24.8 & 21.8 & 23.4 & 23.1 & 22.7 & 19.0 & 19.9 & 20.1 & 19.1 & 17.9 & 20.6 & 21.0 & 21.6 & 20.9 & 19.5 & 19.8 & 22.0 & 18.9 & 25.0 & 21.9 & 22.4 & 20.1 \\
\hline $\mathrm{N}$ & $\mathrm{E}$ & 5.9 & 5.7 & 5.6 & 4.9 & 5.3 & 5.4 & 5.3 & 4.8 & 4.8 & 4.9 & 4.8 & 4.3 & 4.6 & 5.4 & 5.1 & 4.8 & 4.5 & 4.9 & 5.1 & 4.7 & 5.3 & 5.3 & 5.2 & 4.9 \\
\hline M & $\mathrm{E}$ & 20.0 & 22.1 & 21.9 & 21.6 & 22.0 & 21.6 & 22.5 & 19.1 & 22.7 & 18.3 & 20.4 & 18.3 & 18.7 & 20.6 & 21.1 & 18.7 & 20.5 & 18.7 & 19.4 & 17.6 & 24.5 & 21.8 & 23.6 & 17.6 \\
\hline \multicolumn{26}{|c|}{ Transitions to unmployment } \\
\hline $\mathrm{E}$ & $\mathrm{U}$ & 1.5 & 1.6 & 1.5 & 1.2 & 1.5 & 1.4 & 1.3 & 0.9 & 1.1 & 0.9 & 0.8 & 0.8 & 1.0 & 1.1 & 1.0 & 0.8 & 0.9 & 0.8 & 0.8 & 0.7 & 0.8 & 0.8 & 0.9 & 0.8 \\
\hline $\mathrm{U}$ & $\mathrm{U}$ & 53.6 & 56.1 & 54.3 & 55.8 & 55.9 & 53.2 & 54.9 & 54.0 & 56.3 & 54.5 & 57.1 & 55.1 & 54.8 & 54.7 & 57.4 & 56.6 & 56.8 & 56.3 & 55.0 & 52.5 & 50.3 & 49.5 & 54.4 & 52.1 \\
\hline $\mathrm{N}$ & $\mathrm{U}$ & 2.2 & 2.5 & 2.4 & 1.8 & 2.1 & 2.0 & 1.9 & 1.5 & 1.8 & 1.5 & 1.5 & 1.3 & 1.5 & 1.9 & 1.5 & 1.2 & 1.5 & 1.4 & 1.6 & 1.2 & 1.4 & 1.4 & 1.3 & 1.3 \\
\hline M & $\mathrm{U}$ & 28.6 & 27.5 & 27.6 & 26.8 & 28.4 & 23.9 & 24.3 & 22.9 & 24.4 & 26.4 & 26.3 & 23.0 & 27.2 & 23.4 & 24.2 & 21.6 & 22.1 & 24.4 & 22.5 & 19.4 & 23.3 & 21.2 & 20.8 & 24.2 \\
\hline \multicolumn{26}{|c|}{ Transitions to no attachment } \\
\hline E & $\mathrm{N}$ & 2.6 & 2.5 & 2.3 & 2.2 & 2.3 & 2.1 & 2.3 & 2.1 & 2.2 & 2.3 & 2.0 & 2.0 & 2.3 & 2.5 & 2.3 & 2.5 & 2.3 & 2.3 & 2.5 & 2.5 & 2.7 & 2.6 & 2.6 & 2.5 \\
\hline $\mathrm{U}$ & $\mathrm{N}$ & 14.2 & 12.3 & 11.6 & 12.8 & 12.2 & 14.0 & 11.3 & 15.1 & 14.1 & 14.4 & 11.9 & 14.0 & 13.8 & 13.7 & 11.2 & 12.7 & 14.0 & 13.3 & 13.2 & 16.7 & 15.3 & 16.4 & 12.4 & 16.2 \\
\hline $\mathrm{N}$ & $\mathrm{N}$ & 90.3 & 90.4 & 90.5 & 91.9 & 91.1 & 90.9 & 91.2 & 92.4 & 92.5 & 92.3 & 92.5 & 93.2 & 92.7 & 91.3 & 92.3 & 92.8 & 92.8 & 92.7 & 92.2 & 92.9 & 92.2 & 92.3 & 92.6 & 92.9 \\
\hline M & $\mathrm{N}$ & 22.2 & 24.5 & 24.8 & 24.6 & 23.5 & 23.6 & 24.5 & 25.8 & 22.9 & 24.3 & 22.3 & 24.1 & 23.9 & 25.5 & 21.1 & 24.8 & 26.5 & 24.7 & 28.0 & 26.0 & 26.5 & 27.9 & 25.4 & 27.8 \\
\hline \multicolumn{26}{|c|}{ Transitions to marginally attachment } \\
\hline $\mathrm{E}$ & M & 0.6 & 0.6 & 0.5 & 0.8 & 0.6 & 0.5 & 0.7 & 0.5 & 0.7 & 0.5 & 0.6 & 0.8 & 0.7 & 0.5 & 0.7 & 0.6 & 0.7 & 0.7 & 0.7 & 0.5 & 0.6 & 0.6 & 0.7 & 0.8 \\
\hline U & M & 9.2 & 8.5 & 9.2 & 9.7 & 8.5 & 9.7 & 11.2 & 11.9 & 9.8 & 11.1 & 11.9 & 13.0 & 10.8 & 10.7 & 9.8 & 9.7 & 9.7 & 10.6 & 9.8 & 11.9 & 9.4 & 12.2 & 10.8 & 11.6 \\
\hline $\mathrm{N}$ & $\mathrm{M}$ & 1.6 & 1.4 & 1.5 & 1.3 & 1.4 & 1.6 & 1.6 & 1.3 & 1.0 & 1.3 & 1.2 & 1.3 & 1.1 & 1.5 & 1.1 & 1.2 & 1.2 & 1.0 & 1.2 & 1.1 & 1.1 & 1.0 & 0.9 & 0.9 \\
\hline M & $\mathrm{M}$ & 29.2 & 25.9 & 25.7 & 27.0 & 26.0 & 30.9 & 28.7 & 32.2 & 30.0 & 31.0 & 31.1 & 34.6 & 30.2 & 30.5 & 33.6 & 34.8 & 30.9 & 32.2 & 30.1 & 37.0 & 25.7 & 29.1 & 30.3 & 30.5 \\
\hline
\end{tabular}


Table A.2: Transition rates for men (\%) between employment (E), unemployment (U), non attachment (N) and marginal attachment (M) from the 1 st quarter of 2003 to the 4 th quarter of 2008.

\begin{tabular}{|c|c|c|c|c|c|c|c|c|c|c|c|c|c|c|c|c|c|c|c|c|c|c|c|c|c|}
\hline & \multicolumn{4}{|c|}{2003} & \multicolumn{4}{|c|}{2004} & \multicolumn{4}{|c|}{2005} & \multicolumn{4}{|c|}{2006} & \multicolumn{4}{|c|}{2007} & \multicolumn{4}{|c|}{2008} \\
\hline & & 1 st & 2 nd & $3 \mathrm{rd}$ & 4 th & 1 st & 2 nd & $3 r d$ & 4 th & 1 st & 2nd & $3 \mathrm{rd}$ & 4 th & 1 st & 2nd & $3 \mathrm{rd}$ & th & 1 st & 2nd & $3 \mathrm{rd}$ & th & st & $2 \mathrm{nd}$ & $3 \mathrm{rd}$ & 4 th \\
\hline \multicolumn{26}{|c|}{ Transitions to employment } \\
\hline $\mathrm{E}$ & $\mathrm{E}$ & 96.1 & 95.9 & 96.1 & 6.4 & 2 & 5.5 & 6.3 & 6.9 & 6.9 & 6.9 & 97.2 & .3 & 6.9 & 96.6 & 96.8 & .9 & 7.0 & 7.2 & 97.2 & 1 & 7.0 & 96.9 & 96.9 & 7.1 \\
\hline $\mathrm{U}$ & $\mathrm{E}$ & 26.7 & 6.6 & 29.5 & 27.1 & 27.7 & 8.1 & 28.8 & 23.7 & 24.2 & 25.0 & 22.7 & & .7 & 24.7 & 24.8 & 24.4 & 2.2 & 4.1 & 25.5 & 3.4 & 9.2 & 6.8 & 27.4 & 26.1 \\
\hline $\mathrm{N}$ & $\mathrm{E}$ & 7.6 & 6.8 & 7.0 & 6.2 & 6.5 & 7.0 & 6.7 & 5.9 & - & 5.9 & 5.9 & & & 6.6 & 5.9 & & 5.4 & 5.7 & 5.8 & 5 & 6.1 & 6.0 & 6.1 & 5.3 \\
\hline M & $\mathrm{E}$ & 24.9 & 27.2 & 27.0 & 26.0 & 6.9 & 5.7 & 31.0 & 3.6 & 7. & 3.4 & 23.5 & 3 & 23.8 & 5.9 & 28.2 & 2.0 & 3. & 2.9 & 25.1 & 1 & 0. & 6.5 & 29.9 & 3.7 \\
\hline \multicolumn{26}{|c|}{ Transitions to unmployment } \\
\hline $\mathrm{E}$ & $\mathrm{U}$ & 1.4 & $1.6^{1}$ & 1.5 & 1.2 & & 3 & 1.2 & 0. & 1. & 0.8 & 0.7 & 0 & 1 & 1.1 & 0 . & & 0. & 0.7 & 0. & & 0.7 & 0.7 & 0.8 & 0.7 \\
\hline $\mathrm{U}$ & $\mathrm{U}$ & 53.9 & 55.7 & 52.6 & 55.1 & 55.2 & 52.9 & 52.6 & 54.9 & 55.6 & 53.9 & 57.3 & 56.9 & 55.9 & 55.7 & 58.4 & 56.9 & 57.7 & 55.2 & 54.5 & 54.5 & 49.1 & 49.2 & 55.0 & 53.3 \\
\hline $\mathrm{N}$ & $\mathrm{U}$ & 2.7 & 2.7 & 2.4 & 1.7 & 2.0 & 1.9 & 1.8 & 1.5 & 1.8 & 1.6 & 1.4 & 1.3 & 1.5 & 1.9 & 1.3 & 1.1 & 1.5 & 1.6 & 1.3 & 1.2 & 1.2 & 1.4 & 1.4 & 1.2 \\
\hline $\mathrm{M}$ & $\mathrm{U}$ & 30.6 & 29.6 & 28.2 & 29.8 & 29.2 & 23.4 & 23.7 & 25.9 & 25.1 & 26.5 & 29.1 & 24.4 & 29.8 & 26.6 & 22.3 & 24.6 & 22.9 & 26.2 & 23.2 & 20.3 & 25.2 & 25.4 & 19.1 & 21.7 \\
\hline \multicolumn{26}{|c|}{ Transitions to no attachm } \\
\hline E & $\mathrm{N}$ & & 1.9 & 1.7 & 18 & & & 1.9 & & & 1.8 & 1.6 & & & & 1. & & & 1 & 1 & & & 1.9 & 1.9 & 1.8 \\
\hline $\mathrm{U}$ & $\mathrm{N}$ & 11.7 & 10.0 & 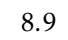 & 0 & 9. & 1.0 & 8.5 & 0.7 & 1 & 11.3 & 9.4 & 10.9 & 10 & 10.9 & 8. & 10.2 & 11.7 & 11.0 & 10.9 & 11.5 & 12.9 & 11.9 & 8.3 & 12.2 \\
\hline $\mathrm{N}$ & $\mathrm{N}$ & 3.0 & 89.1 & 9.1 & 0.7 & 89.9 & 9.4 & 90.2 & 91.5 & 91 & 91.2 & 91.5 & 92.7 & 91 & 90.0 & 91.9 & 91.8 & 92.2 & 91.8 & 92.0 & 92.5 & 91.7 & 91.8 & 91.7 & 92.8 \\
\hline $\mathrm{M}$ & $\mathrm{N}$ & 19.6 & 20.4 & 21.0 & 19.0 & 20.7 & 20.3 & 20.1 & 21.3 & 16.8 & 21.3 & 18.1 & 23.1 & 21.6 & 19.4 & 17.4 & 21.2 & 20.3 & 21.0 & 23.7 & 20.6 & 21.9 & 20.8 & 19.9 & 23.5 \\
\hline \multicolumn{26}{|c|}{ Transitions to marginally attachment } \\
\hline E & $\mathrm{M}$ & 0.5 & 0.5 & 0.5 & 0.7 & 0.6 & 0.4 & 0.7 & 0. & 0.6 & 0.5 & 0.6 & 0.6 & 0. & 0.5 & 0.7 & 0.5 & 0. & 0.7 & 0.6 & .1 & 0.6 & 0.5 & 0.7 & 0.7 \\
\hline U & $\mathrm{M}$ & 7.7 & 7.7 & 9.0 & 7.8 & 7.2 & 8.0 & 10.1 & 10.8 & 9.0 & 9.7 & 10.6 & 11.0 & 9.9 & 8.7 & 8.1 & 8.6 & 8.4 & 9.6 & 9.1 & 10.6 & 8.8 & 12.1 & 9.2 & 8.4 \\
\hline $\mathrm{N}$ & $\mathrm{M}$ & 1.7 & 1.4 & 1.5 & 1.4 & 1.6 & 1.7 & 1.3 & 1.1 & 1.0 & 1.3 & 1.1 & 1.3 & 1.1 & 1.4 & 0.9 & 1.0 & 0.9 & 0.9 & 0.9 & 0.9 & 0.9 & 0.8 & 0.7 & 0.7 \\
\hline M & $\mathrm{M}$ & 24.9 & 22.9 & 23.8 & 25.2 & 23.3 & 30.6 & 25.2 & 29.2 & 30.3 & 28.8 & 29.3 & 29.1 & 24.7 & 28.2 & 32.0 & 32.2 & 28.7 & 29.9 & 28.0 & 38.1 & 22.7 & 27.3 & 31.0 & 31.5 \\
\hline
\end{tabular}

Source: Elaborated by the authors based on PME microdata for 2003 to 2008 . 
Table A.3: Transition rates for women (\%) between employment (E), unemployment (U), non attachment (N) and marginal attachment (M) from the 1st quarter of 2003 to the 4 th quarter of 2008.

\begin{tabular}{|c|c|c|c|c|c|c|c|c|c|c|c|c|c|c|c|c|c|c|c|c|c|c|c|c|c|}
\hline & & \multicolumn{4}{|c|}{2003} & \multicolumn{4}{|c|}{2004} & \multicolumn{4}{|c|}{2005} & \multicolumn{4}{|c|}{2006} & \multicolumn{4}{|c|}{2007} & \multicolumn{4}{|c|}{2008} \\
\hline & & $1 \mathrm{st}$ & 2nd & $3 \mathrm{rd}$ & 4 th & 1 st & 2nd & $3 \mathrm{rd}$ & 4 th & 1 st & 2nd & $3 r d$ & 4 th & $1 \mathrm{st}$ & $2 \mathrm{nd}$ & $3 \mathrm{rd}$ & 4 th & $1 \mathrm{st}$ & $2 \mathrm{nd}$ & $3 \mathrm{rd}$ & 4 th & $1 \mathrm{st}$ & $2 \mathrm{nd}$ & $3 \mathrm{rd}$ & 4 th \\
\hline \multicolumn{26}{|c|}{ Transitions to employment } \\
\hline E & $\mathrm{E}$ & 92.9 & 93.4 & 93.8 & 94.4 & 93.7 & 94.2 & 94.2 & 94.3 & 94.1 & 94.7 & 95.0 & 94.8 & 94.1 & 93.8 & 94.4 & 94.2 & 94.6 & 94.3 & 93.9 & 94.2 & 93.3 & 94.2 & 94.0 & 93.8 \\
\hline U & $\mathrm{E}$ & 16.3 & 16.0 & 16.4 & 13.0 & 16.6 & 15.4 & 13.8 & 12.8 & 13.8 & 13.7 & 14.4 & 13.9 & 16.8 & 15.9 & 17.3 & 16.1 & 16.0 & 14.4 & 18.4 & 13.9 & 20.3 & 16.4 & 17.4 & 14.6 \\
\hline $\mathrm{N}$ & $\mathrm{E}$ & 4.5 & 4.6 & 4.4 & 3.8 & 4.3 & 4.0 & 4.1 & 3.9 & 4.0 & 4.0 & 3.9 & 3.8 & 3.8 & 4.3 & 4.5 & 3.9 & 3.9 & 4.3 & 4.5 & 4.1 & 4.6 & 4.7 & 4.4 & 4.5 \\
\hline M & $\mathrm{E}$ & 14.1 & 15.5 & 15.4 & 15.7 & 16.9 & 16.5 & 13.7 & 13.9 & 17.0 & 13.0 & 17.0 & 13.5 & 14.4 & 16.0 & 14.3 & 15.3 & 14.1 & 14.4 & 14.4 & 14.4 & 19.8 & 17.8 & 17.5 & 12.2 \\
\hline \multicolumn{26}{|c|}{ Transitions to unmployment } \\
\hline E & $\mathrm{U}$ & 1.7 & $1.3^{1}$ & 1.6 & 1.2 & 1.5 & 1.5 & 1.4 & 0.1 & 1.4 & 1.0 & 1.0 & 0.9 & 1.1 & 1.1 & 1.2 & 0.9 & 1.0 & 1.1 & 1.1 & 1.0 & 1.1 & 1.0 & 1.1 & 1.1 \\
\hline $\mathrm{U}$ & $\mathrm{U}$ & 52.9 & 56.9 & 57.4 & 56.8 & 57.1 & 53.7 & 58.1 & 52.7 & 57.3 & 55.2 & 56.8 & 52.9 & 53.4 & 53.3 & 56.1 & 56.3 & 55.6 & 57.7 & 55.6 & 50.4 & 51.5 & 49.8 & 53.7 & 51.1 \\
\hline $\mathrm{N}$ & $\mathrm{U}$ & 1.8 & 2.2 & 2.5 & 2.0 & 2.2 & 2.0 & 2.0 & 1.6 & 1.7 & 1.5 & 1.6 & 1.4 & 1.5 & 1.9 & 1.6 & 1.3 & 1.6 & 1.2 & 1.8 & 1.3 & 1.5 & 1.4 & 1.3 & 1.4 \\
\hline $\mathrm{M}$ & $\mathrm{U}$ & 26.3 & 24.7 & 26.8 & 22.9 & 27.6 & 24.6 & 24.9 & 19.5 & 23.5 & 26.4 & 23.1 & 21.7 & 25.0 & 20.5 & 25.9 & 18.4 & 21.5 & 22.6 & 21.9 & 18.7 & 21.7 & 17.5 & 22.3 & 26.3 \\
\hline \multicolumn{26}{|c|}{ Transitions to no attachment } \\
\hline E & $\mathrm{N}$ & 4.7 & 4.4 & 4.0 & 3.6 & 3.9 & 3.4 & 3.7 & 3.7 & 3.7 & 3.5 & 3.2 & 3.4 & 4.0 & 4.3 & 3.6 & 4.2 & 3.7 & 3.9 & 4.4 & 4.2 & 4.8 & 4.2 & 4.3 & 4.3 \\
\hline $\mathrm{U}$ & $\mathrm{N}$ & 18.9 & 16.8 & 16.6 & 17.4 & 15.9 & 18.5 & 15.3 & 21.0 & 18.1 & 18.3 & 15.1 & 17.7 & 17.9 & 17.4 & 14.4 & 16.2 & 17.0 & 16.0 & 15.6 & 22.5 & 17.9 & 21.5 & 16.5 & 19.8 \\
\hline $\mathrm{N}$ & $\mathrm{N}$ & 92.2 & 91.7 & 91.7 & 93.0 & 92.2 & 92.4 & 92.0 & 93.1 & 93.2 & 93.3 & 93.4 & 93.6 & 93.5 & 92.3 & 92.6 & 93.5 & 93.2 & 93.5 & 92.3 & 93.2 & 92.6 & 92.7 & 93.2 & 93.0 \\
\hline M & $\mathrm{N}$ & 25.3 & 29.9 & 29.7 & 31.9 & 26.6 & 27.7 & 29.0 & 31.0 & 29.8 & 27.4 & 26.8 & 25.1 & 25.8 & 31.0 & 24.7 & 28.6 & 31.6 & 28.4 & 31.7 & 30.9 & 30.3 & 34.2 & 30.7 & 31.5 \\
\hline \multicolumn{26}{|c|}{ Transitions to marginally attachment } \\
\hline $\mathrm{E}$ & M & 0.9 & 0.9 & 0.5 & 1.1 & 0.7 & 0.9 & 0.7 & 0.6 & 0.7 & 0.6 & 0.6 & 1.1 & 0.9 & 0.8 & 0.7 & 0.7 & 1.0 & 0.8 & 0.8 & 0.7 & 0.7 & 0.8 & 0.7 & 1.1 \\
\hline U & $\mathrm{M}$ & 11.9 & 10.3 & 9.6 & 12.9 & 10.4 & 12.4 & 12.8 & 13.5 & 10.9 & 12.8 & 13.7 & 15.5 & 11.9 & 13.4 & 12.1 & 11.4 & 11.4 & 11.9 & 10.5 & 13.2 & 10.2 & 12.3 & 12.4 & 14.5 \\
\hline $\mathrm{N}$ & $\mathrm{M}$ & 1.5 & 1.4 & 1.4 & 1.3 & 1.3 & 1.6 & 1.9 & 1.4 & 1.0 & 1.2 & 1.2 & 1.3 & 1.2 & 1.5 & 1.3 & 1.3 & 1.4 & 1.0 & 1.4 & 1.4 & 1.2 & 1.2 & 1.1 & 1.1 \\
\hline M & $\mathrm{M}$ & 34.3 & 29.9 & 28.1 & 29.4 & 28.9 & 31.2 & 32.4 & 35.6 & 29.6 & 33.2 & 33.0 & 39.8 & 34.9 & 32.5 & 35.1 & 37.6 & 32.8 & 34.6 & 31.9 & 36.0 & 28.3 & 30.6 & 29.5 & 29.9 \\
\hline
\end{tabular}


Table A.4: Conditional transition probabilities for $\mathrm{E}$ or $\mathrm{N}$, from $\mathrm{U}$ or $\mathrm{M}$ - Unrestricted and restricted multinomial logit estimation

\begin{tabular}{|c|c|c|c|c|c|c|}
\hline \multirow{2}{*}{ Variables } & \multicolumn{2}{|c|}{ Total } & \multicolumn{2}{|c|}{ Men } & \multicolumn{2}{|c|}{ Women } \\
\hline & $\begin{array}{l}\text { Unrestricted } \\
\text { Model }\end{array}$ & $\begin{array}{l}\text { Restricted } \\
\text { Model }\end{array}$ & $\begin{array}{l}\text { Unrestricted } \\
\text { Model }\end{array}$ & $\begin{array}{l}\text { Restricted } \\
\text { Model }\end{array}$ & $\begin{array}{l}\text { Unrestricted } \\
\text { Model }\end{array}$ & $\begin{array}{l}\text { Restricted } \\
\text { Model }\end{array}$ \\
\hline \multicolumn{7}{|l|}{ Years of Schooling: } \\
\hline Between 1 and 3 years & $\begin{array}{l}0.0784 \\
(0.08)\end{array}$ & $\begin{array}{l}0.0682 \\
(0.06)\end{array}$ & $\begin{array}{l}0.203 \\
(0.11)\end{array}$ & $\begin{array}{l}0.228 \\
(0.09)\end{array}$ & $\begin{array}{l}0.113 \\
(0.13)\end{array}$ & $\begin{array}{l}0.172 \\
(0.10)\end{array}$ \\
\hline Between 4 and 7 years & $\begin{array}{l}0.0137 \\
(0.07)\end{array}$ & $\begin{array}{l}0.0278 \\
(0.06)\end{array}$ & $\begin{array}{l}0.223 \\
(0.10)\end{array}$ & $\begin{array}{l}0.24 \\
(0.08)\end{array}$ & $\begin{array}{l}0.322 \\
(0.12)\end{array}$ & $\begin{array}{l}0.303 \\
(0.09)\end{array}$ \\
\hline Between 8 and 10 years & $\begin{array}{l}0.0275 \\
(0.08)\end{array}$ & $\begin{array}{l}0.0718 \\
(0.06)\end{array}$ & $\begin{array}{l}0.265 \\
(0.11)\end{array}$ & $\begin{array}{l}0.316 \\
(0.08)\end{array}$ & $\begin{array}{l}0.339 \\
(0.12)\end{array}$ & $\begin{array}{l}0.287 \\
(0.09)\end{array}$ \\
\hline 11 or more years & $\begin{array}{l}0.195 \\
(0.07)\end{array}$ & $\begin{array}{l}0.232 \\
(0.06)\end{array}$ & $\begin{array}{l}0.621 \\
(0.10)\end{array}$ & $\begin{array}{l}0.647 \\
(0.08)\end{array}$ & $\begin{array}{l}0.385 \\
(0.12)\end{array}$ & $\begin{array}{l}0.308 \\
(0.09)\end{array}$ \\
\hline Female & $\begin{array}{l}1.177 \\
(0.03)\end{array}$ & $\begin{array}{l}1.159 \\
(0.02)\end{array}$ & - & - & - & - \\
\hline White & $\begin{array}{c}-0.0318 \\
(0.03)\end{array}$ & $\begin{array}{c}-0.0163 \\
(0.02)\end{array}$ & $\begin{array}{c}-0.0496 \\
(0.04)\end{array}$ & $\begin{array}{c}-0.0129 \\
(0.03)\end{array}$ & $\begin{array}{c}-0.000362 \\
(0.04)\end{array}$ & $\begin{array}{c}-0.0106 \\
(0.03)\end{array}$ \\
\hline Age & $\begin{array}{c}-0.113 \\
(0.01)\end{array}$ & $\begin{array}{c}-0.101 \\
(0.01)\end{array}$ & $\begin{array}{c}-0.0814 \\
(0.01)\end{array}$ & $\begin{array}{c}-0.0746 \\
(0.01)\end{array}$ & $\begin{array}{r}-0.105 \\
(0.01)\end{array}$ & $\begin{array}{c}-0.0914 \\
(0.01)\end{array}$ \\
\hline Age Squared & $\begin{array}{l}0.00185 \\
(0.00)\end{array}$ & $\begin{array}{l}0.00169 \\
(0.00)\end{array}$ & $\begin{array}{l}0.00163 \\
(0.00)\end{array}$ & $\begin{array}{l}0.00153 \\
(0.00)\end{array}$ & $\begin{array}{l}-0.00153 \\
(0.00)\end{array}$ & $\begin{array}{c}-0.00137 \\
(0.00)\end{array}$ \\
\hline Marginally Attached & $\begin{array}{c}-0.0422 \\
(0.30)\end{array}$ & - & $\begin{array}{l}0.171 \\
(0.44)\end{array}$ & - & - & - \\
\hline \multicolumn{7}{|c|}{ Interactions with the Marginally Attached: } \\
\hline Between 1 and 3 years & $\begin{array}{c}-0.0531 \\
(0.13)\end{array}$ & - & $\begin{array}{l}0.0165 \\
(0.18)\end{array}$ & - & $\begin{array}{l}0.144 \\
(0.20)\end{array}$ & - \\
\hline Between 4 and 7 years & $\begin{array}{l}0.00771 \\
(0.11)\end{array}$ & - & $\begin{array}{l}0.00686 \\
(0.16)\end{array}$ & - & $\begin{array}{c}-0.0331 \\
(0.18)\end{array}$ & - \\
\hline Between 8 and 10 years & $\begin{array}{l}0.0878 \\
(0.12)\end{array}$ & - & $\begin{array}{l}0.11 \\
(0.17)\end{array}$ & - & $\begin{array}{c}-1.105 \\
(0.18)\end{array}$ & - \\
\hline 11 or more years & $\begin{array}{l}0.123 \\
(0.12)\end{array}$ & - & $\begin{array}{l}0.0998 \\
(0.16)\end{array}$ & - & $\begin{array}{c}-0.22 \\
(0.18)\end{array}$ & - \\
\hline Female & $\begin{array}{c}-0.128 \\
(0.05)\end{array}$ & - & - & - & $\begin{array}{l}0.346 \\
(0.43)\end{array}$ & - \\
\hline White & $\begin{array}{l}0.0793 \\
(0.05)\end{array}$ & - & $\begin{array}{l}0.137 \\
(0.07)\end{array}$ & - & $\begin{array}{c}-0.0122 \\
(0.07)\end{array}$ & - \\
\hline Age & $\begin{array}{l}0.0342 \\
(0.01)\end{array}$ & - & $\begin{array}{l}0.0225 \\
(0.02)\end{array}$ & - & $\begin{array}{c}-0.0386 \\
(0.02)\end{array}$ & - \\
\hline Age Squared & $-\underset{(0.00)}{0.000492}$ & - & $-\underset{(0.00)}{0.000366}$ & - & $\begin{array}{l}0.000482 \\
(0.00)\end{array}$ & - \\
\hline Constant & $\begin{array}{l}0.256 \\
(0.19)\end{array}$ & $\begin{array}{l}0.21 \\
(0.15)\end{array}$ & $\begin{array}{r}-0.917 \\
(0.28)\end{array}$ & $\begin{array}{c}-0.876 \\
(0.21)\end{array}$ & $\begin{array}{r}-2.041 \\
(0.28)\end{array}$ & $\begin{array}{c}-1.907 \\
(0.21)\end{array}$ \\
\hline Observations & 33557 & 33557 & 18595 & 18595 & 14962 & 14962 \\
\hline Log Likelihood & -20676 & -20895 & -10717 & -10841 & -9870 & -9967 \\
\hline
\end{tabular}

Source: Elaborated by the authors based on PME microdata for 2003 to 2008.

Note: Standard deviation in brackets. 
Table A.5: Conditional transition probabilities for $\mathrm{E}$ or $\mathrm{U}$, from $\mathrm{N}$ or $\mathrm{M}$ - Unrestricted and restricted multinomial logit estimation

\begin{tabular}{|c|c|c|c|c|c|c|}
\hline \multirow{2}{*}{ Variables } & \multicolumn{2}{|c|}{ Total } & \multicolumn{2}{|c|}{ Men } & \multicolumn{2}{|c|}{ Women } \\
\hline & $\begin{array}{l}\text { Unrestricted } \\
\text { Model }\end{array}$ & $\begin{array}{c}\text { Restricted } \\
\text { Model }\end{array}$ & $\begin{array}{c}\text { Unrestricted } \\
\text { Model }\end{array}$ & $\begin{array}{l}\text { Restricted } \\
\text { Model }\end{array}$ & $\begin{array}{c}\text { Unrestricted } \\
\text { Model }\end{array}$ & $\begin{array}{c}\text { Restricted } \\
\text { Model }\end{array}$ \\
\hline \multicolumn{7}{|l|}{ Years of Schooling: } \\
\hline Between 1 and 3 years & $\begin{array}{c}-0.12 \\
(0.07)\end{array}$ & $\begin{array}{c}-0.0456 \\
(0.05)\end{array}$ & $\begin{array}{c}-0.25 \\
(0.09)\end{array}$ & $\begin{array}{c}-0.166 \\
(0.08)\end{array}$ & $-\underset{(0.09)}{0.00572}$ & $\begin{array}{l}0.0812 \\
(0.08)\end{array}$ \\
\hline Between 4 and 7 years & $\begin{array}{c}-0.0889 \\
(0.06)\end{array}$ & $\begin{array}{c}-0.0315 \\
(0.05)\end{array}$ & $\begin{array}{r}-0.24 \\
(0.09)\end{array}$ & $\begin{array}{c}-0.158 \\
(0.07)\end{array}$ & $\begin{array}{l}0.0347 \\
(0.09)\end{array}$ & $\begin{array}{l}0.0924 \\
(0.07)\end{array}$ \\
\hline Between 8 and 10 years & $\begin{array}{l}0.0442 \\
(0.06)\end{array}$ & $\begin{array}{l}0.142 \\
(0.05)\end{array}$ & $\begin{array}{c}-0.0563 \\
(0.09)\end{array}$ & $\begin{array}{l}0.0785 \\
(0.07)\end{array}$ & $\begin{array}{l}0.12 \\
(0.09)\end{array}$ & $\begin{array}{l}0.198 \\
(0.07)\end{array}$ \\
\hline 11 or more years & $\begin{array}{l}0.138 \\
(0.06)\end{array}$ & $\begin{array}{l}0.286 \\
(0.05)\end{array}$ & $\begin{array}{l}0.0477 \\
(0.08)\end{array}$ & $\begin{array}{l}0.214 \\
(0.07)\end{array}$ & $\begin{array}{l}0.198 \\
(0.08)\end{array}$ & $\begin{array}{l}0.343 \\
(0.07)\end{array}$ \\
\hline Female & $\begin{array}{l}0.14 \\
(0.03)\end{array}$ & $\begin{array}{l}0.121 \\
(0.02)\end{array}$ & - & - & - & - \\
\hline White & $\begin{array}{c}-0.186 \\
(0.03)\end{array}$ & $\begin{array}{c}-0.192 \\
(0.02)\end{array}$ & $\begin{array}{c}-0.145 \\
(0.04)\end{array}$ & $\begin{array}{c}-0.169 \\
(0.03)\end{array}$ & $\begin{array}{c}-0.223 \\
(0.04)\end{array}$ & $\begin{array}{c}-0.215 \\
(0.03)\end{array}$ \\
\hline Age & $-\underset{(0.01)}{0.00145}$ & $\begin{array}{l}0.0281 \\
(0.01)\end{array}$ & $\begin{array}{l}0.0158 \\
(0.01)\end{array}$ & $\begin{array}{l}0.0414 \\
(0.01)\end{array}$ & $\begin{array}{l}0.000818 \\
(0.01)\end{array}$ & $\begin{array}{l}0.0289 \\
(0.01)\end{array}$ \\
\hline Age Squared & $-\underset{(0.00)}{0.000547}$ & $-\underset{(0.00)}{0.000857}$ & $-\underset{(0.00)}{0.000651}$ & $-\underset{(0.00)}{0.000928}$ & $-\underset{(0.00)}{0.000658}$ & $\begin{array}{c}-0.00096 \\
(0.00)\end{array}$ \\
\hline Marginally Attached & $\begin{array}{c}-0.204 \\
(0.27)\end{array}$ & - & $\begin{array}{l}0.161 \\
(0.38)\end{array}$ & - & - & - \\
\hline \multicolumn{7}{|c|}{ Interactions with the Marginally Attached: } \\
\hline Between 1 and 3 years & $\begin{array}{l}0.15 \\
(0.12)\end{array}$ & - & $\begin{array}{l}0.229 \\
(0.16)\end{array}$ & - & $\begin{array}{l}0.117 \\
(0.19)\end{array}$ & - \\
\hline Between 4 and 7 years & $\begin{array}{l}0.161 \\
(0.11)\end{array}$ & - & $\begin{array}{l}0.303 \\
(0.14)\end{array}$ & - & $\begin{array}{l}0.0422 \\
(0.17)\end{array}$ & - \\
\hline Between 8 and 10 years & $\begin{array}{l}0.23 \\
(0.11)\end{array}$ & - & $\begin{array}{l}0.42 \\
(0.15)\end{array}$ & - & $\begin{array}{l}0.0205 \\
(0.18)\end{array}$ & - \\
\hline 11 or more years & $\begin{array}{l}0.392 \\
(0.11)\end{array}$ & - & $\begin{array}{l}0.578 \\
(0.14)\end{array}$ & - & $\begin{array}{l}0.192 \\
(0.18)\end{array}$ & - \\
\hline Female & $\begin{array}{l}0.231 \\
(0.05)\end{array}$ & - & - & - & $\underset{(0.40)}{-0.0414}$ & - \\
\hline White & $\begin{array}{l}0.113 \\
(0.05)\end{array}$ & - & $\begin{array}{l}0.0625 \\
(0.06)\end{array}$ & - & $\begin{array}{l}0.172 \\
(0.07)\end{array}$ & - \\
\hline Age & $-\underset{(0.01)}{0.00504}$ & - & $\begin{array}{c}-0.0232 \\
(0.02)\end{array}$ & - & $\begin{array}{l}0.00426 \\
(0.02)\end{array}$ & - \\
\hline Age Squared & $\begin{array}{l}0.000534 \\
(0.00)\end{array}$ & - & $\begin{array}{l}0.000704 \\
(0.00)\end{array}$ & - & $\begin{array}{l}0.000411 \\
(0.00)\end{array}$ & - \\
\hline Constant & $\begin{array}{l}0.294 \\
(0.15) \\
\end{array}$ & $\begin{array}{r}-0.146 \\
(0.12)\end{array}$ & $\begin{array}{c}-0.184 \\
(0.23) \\
\end{array}$ & $\begin{array}{r}-0.511 \\
(0.17) \\
\end{array}$ & $\begin{array}{l}0.489 \\
(0.21) \\
\end{array}$ & $\begin{array}{l}0.0657 \\
(0.17)\end{array}$ \\
\hline Observations & 46836 & 46836 & 24311 & 24311 & 22525 & 22525 \\
\hline Log Likelihood & -25913 & -26996 & -13108 & -13666 & -12786 & -13309 \\
\hline
\end{tabular}

Source: Elaborated by the authors based on PME microdata for 2003 to 2008 .

Note: Standard deviation in brackets. 


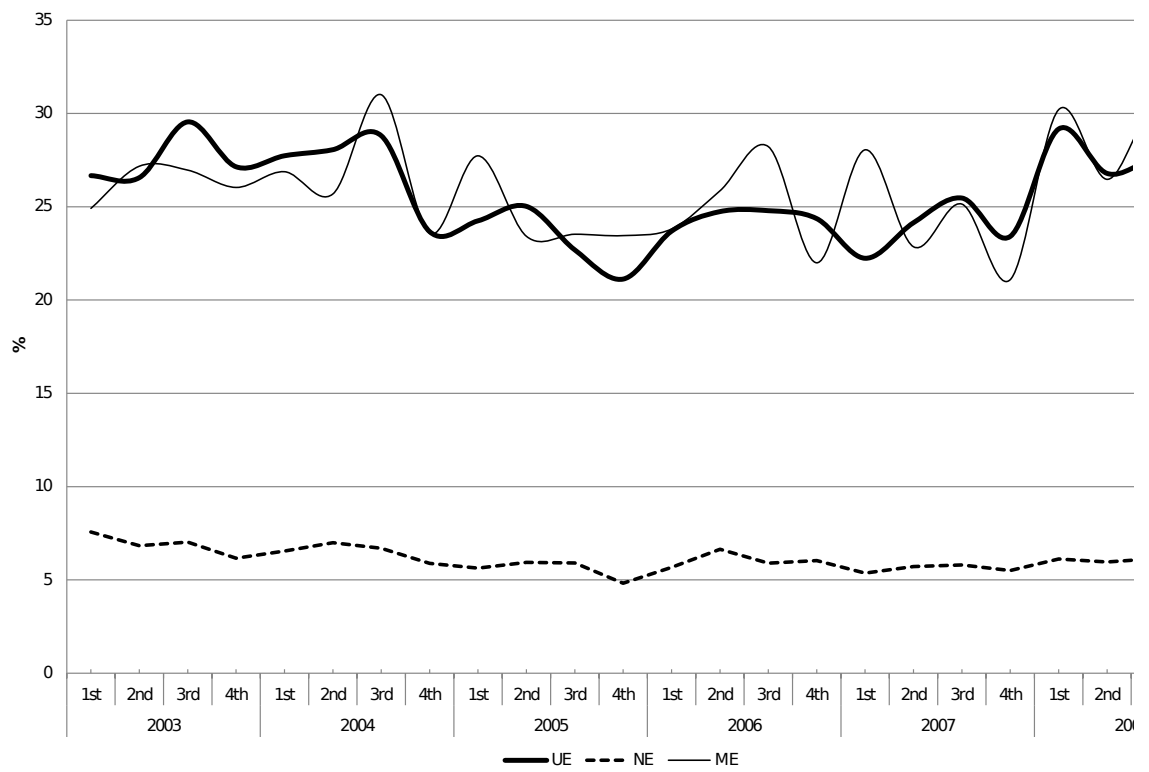

Source: Elaborated by the authors based on the PME microdata for 2003 to 2008 .

Figure A.1: Quarterly transition rates to unemployment for men

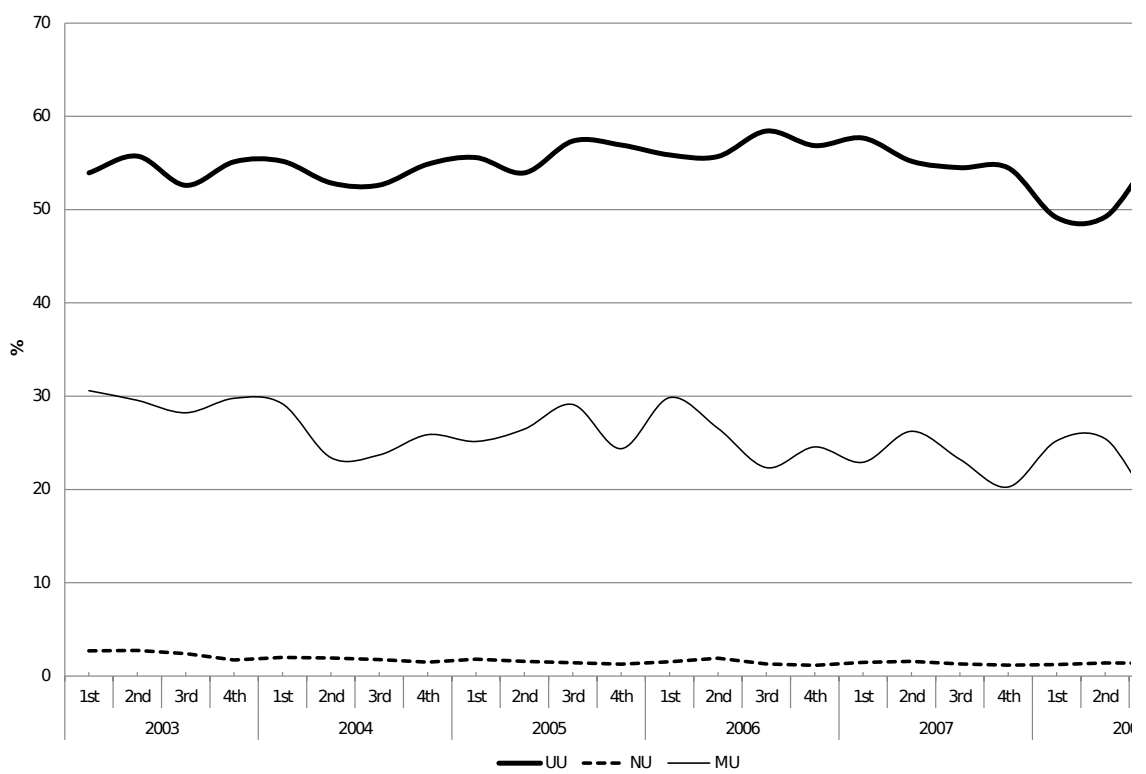

Source: Elaborated by the authors based on the PME microdata for 2003 to 2008 .

Figure A.2: Quarterly transition rates to unemployment for men 


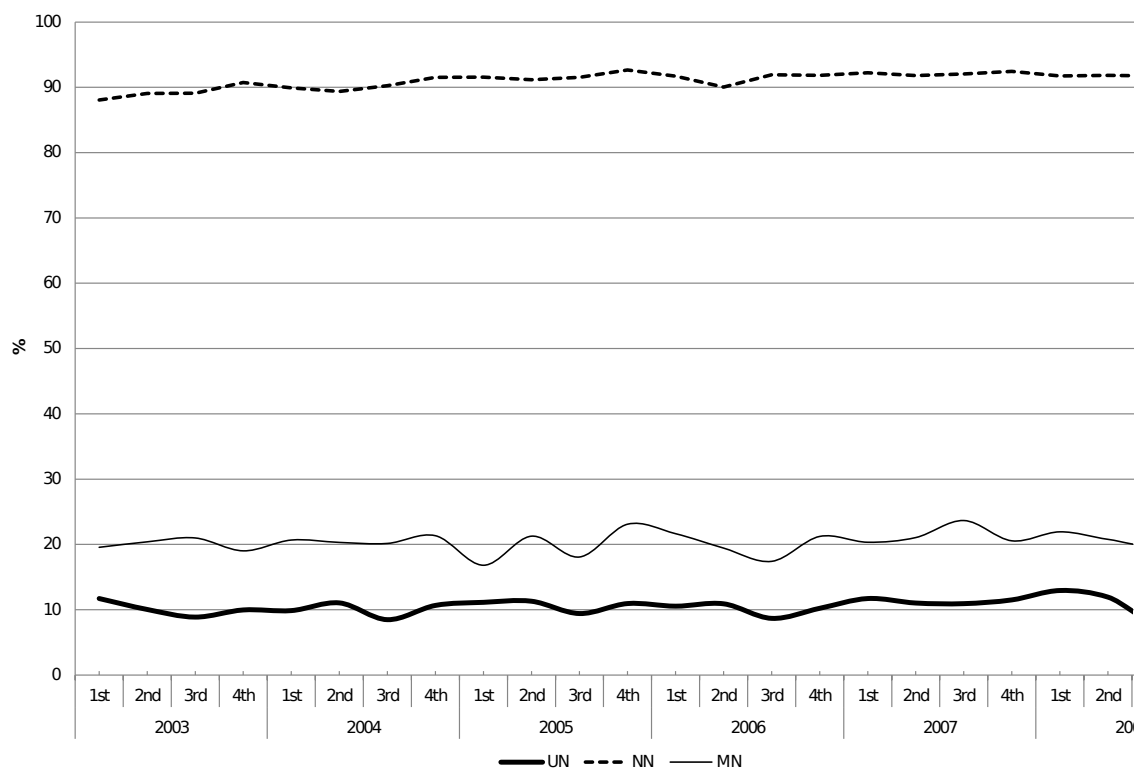

Source: Elaborated by the authors based on the PME microdata for 2003 to 2008 .

Figure A.3: Quarterly transition rates to unemployment for men

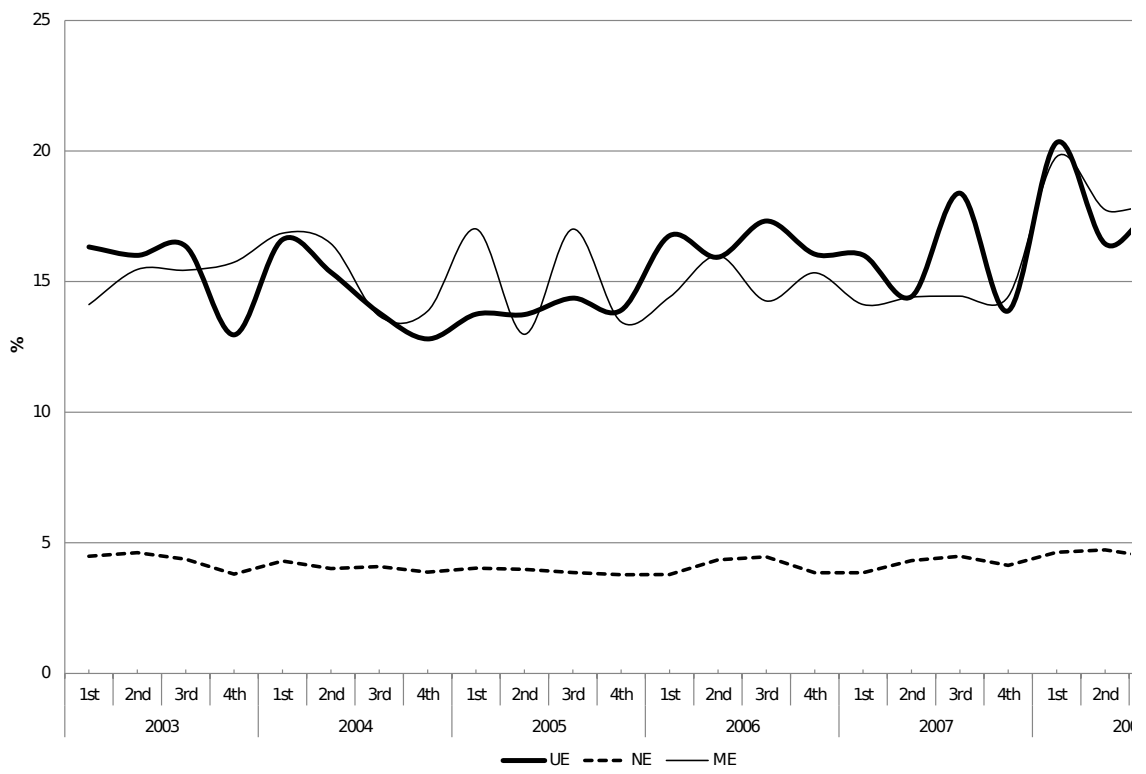

Source: Elaborated by the authors based on the PME microdata for 2003 to 2008 .

Figure A.4: Quarterly transition rates to unemployment for women 


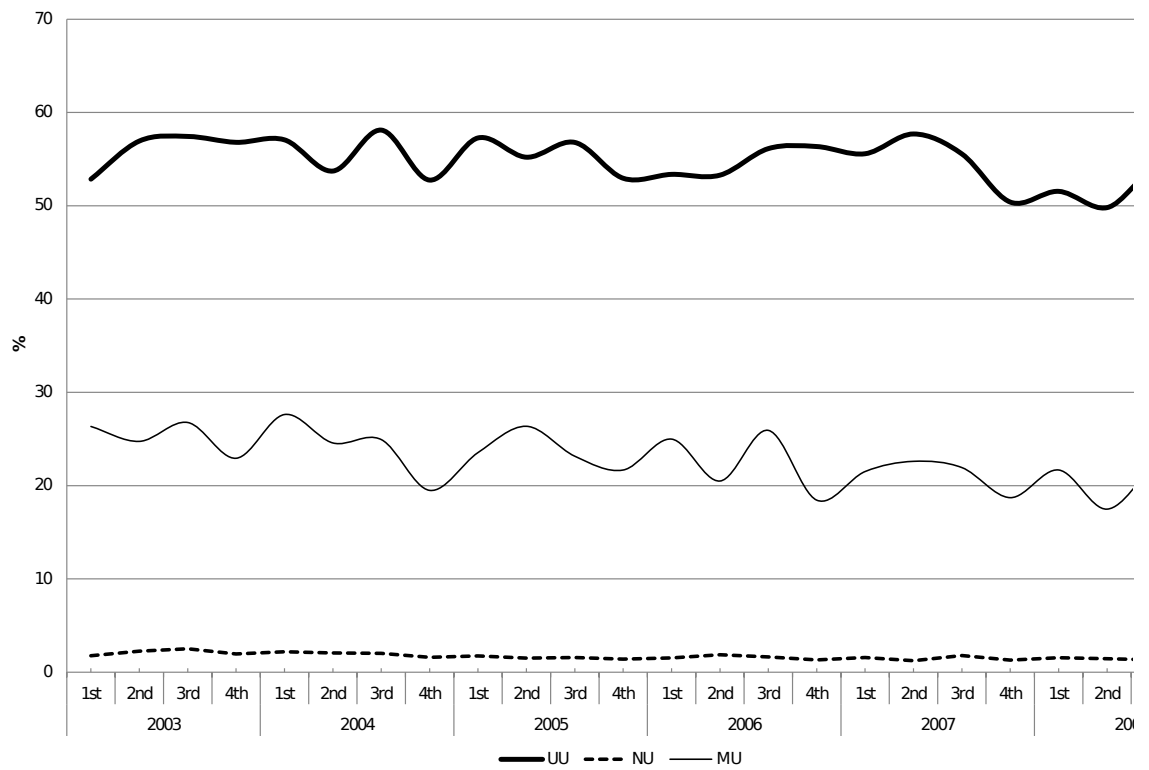

Source: Elaborated by the authors based on the PME microdata for 2003 to 2008.

Figure A.5: Quarterly transition rates to unemployment for women

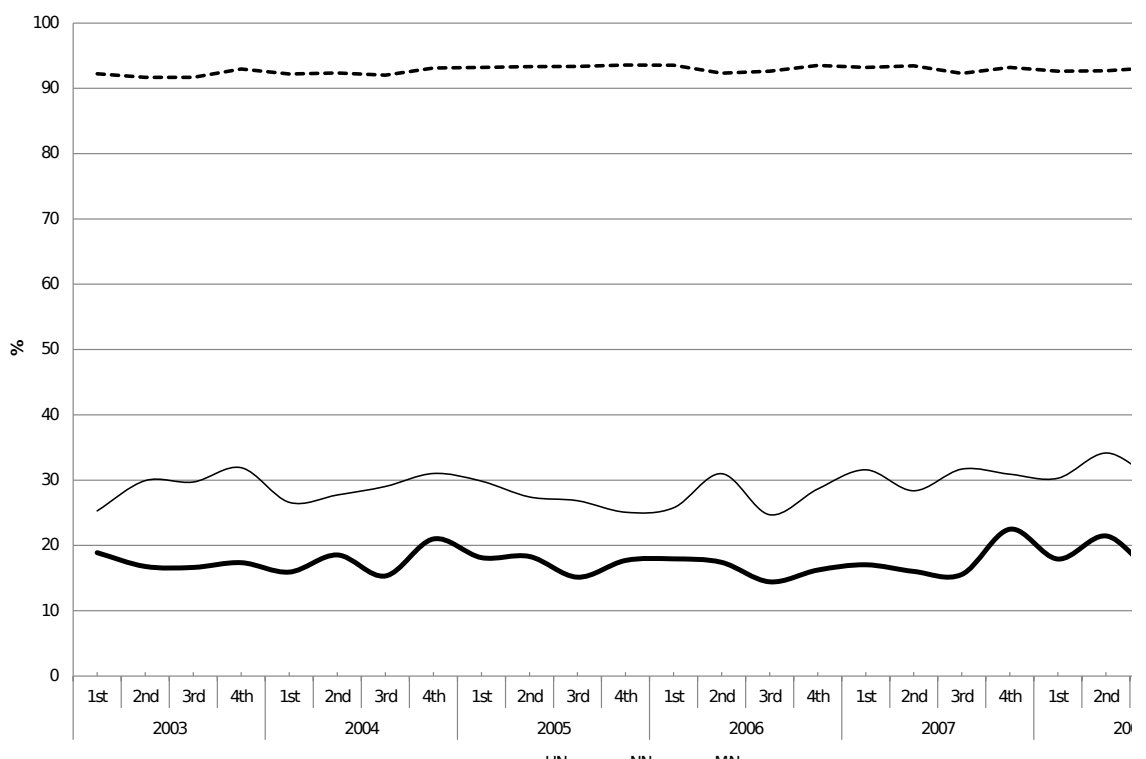

Source: Elaborated by the authors based on the PME microdata for 2003 to 2008 .

Figure A.6: Quarterly transition rates to unemployment for women 